\title{
Roles for androgens in mediating the sex differences of neuroendocrine and behavioral stress responses
}

\author{
Damian G. Zuloaga', Ashley L. Heck², Rose M. De Guzman ${ }^{1}$ and Robert J. Handa ${ }^{2 *}$ (D)
}

\begin{abstract}
Estradiol and testosterone are powerful steroid hormones that impact brain function in numerous ways. During development, these hormones can act to program the adult brain in a male or female direction. During adulthood, gonadal steroid hormones can activate or inhibit brain regions to modulate adult functions. Sex differences in behavioral and neuroendocrine (i.e., hypothalamic pituitary adrenal (HPA) axis) responses to stress arise as a result of these organizational and activational actions. The sex differences that are present in the HPA and behavioral responses to stress are particularly important considering their role in maintaining homeostasis. Furthermore, dysregulation of these systems can underlie the sex biases in risk for complex, stress-related diseases that are found in humans. Although many studies have explored the role of estrogen and estrogen receptors in mediating sex differences in stress-related behaviors and HPA function, much less consideration has been given to the role of androgens. While circulating androgens can act by binding and activating androgen receptors, they can also act by metabolism to estrogenic molecules to impact estrogen signaling in the brain and periphery. This review focuses on androgens as an important hormone for modulating the HPA axis and behaviors throughout life and for setting up sex differences in key stress regulatory systems that could impact risk for disease in adulthood. In particular, impacts of androgens on neuropeptide systems known to play key roles in HPA and behavioral responses to stress (corticotropin-releasing factor, vasopressin, and oxytocin) are discussed. A greater knowledge of androgen action in the brain is key to understanding the neurobiology of stress in both sexes.
\end{abstract}

Keywords: Testosterone, Estrogen, HPA axis, Anxiety, Depression, Glucocorticoids, Androgen receptor, Estrogen receptor, Hypothalamus

\section{Introduction}

The reproductive hormones, estradiol (E2) and testosterone $(\mathrm{T})$, act on the brain to control important neurobiological functions, which include stress-related behaviors, cognition, neuroendocrine function, autonomic function, feeding, and metabolism [1-4]. The neurobiological effects of E2 and T are partly linked to their regulation of

\footnotetext{
* Correspondence: bhanda@colostate.edu

${ }^{2}$ Department of Biomedical Sciences, Colorado State University, Fort Collins, $\mathrm{CO}$, USA

Full list of author information is available at the end of the article
}

hypothalamic function, particularly the hypothalamicpituitary-adrenal (HPA) axis, through changes in circulating glucocorticoid (GC) levels. Not only can GCs affect behaviors, but chronic elevations of GCs promote the development of neurological disorders [5], cardiovascular disease [6], obesity, and metabolic syndrome [7]. Clinical and preclinical studies show compelling evidence for a link between anxiety and depression, cardiometabolic disease, and obesity, with a dysregulation of the HPA axis [8, 9]. Moreover, sex differences are present in the risk for such disorders that may be related to gonadal hormone actions, as both E2 and T modulate the HPA axis [10]. 
Although much is known about the cellular and molecular actions of estrogens and how these hormones can regulate the HPA axis and stress-related behaviors, much less has been published regarding role(s) for androgens in stress hormone and behavioral responses to stress. In this review, we will address the multimodal actions of androgens in modulating the HPA axis as well as its neurobiological actions that can regulate stress-related behaviors. These include not only androgens acting through classical androgen receptor (AR) mechanisms, but also androgen metabolism to compounds that may bind with differing affinities to the AR or act through binding to estrogen receptors (ERs).

\section{Overview of the hypothalamic-pituitary-adrenal axis}

Animals respond to threats to their welfare with the activation of neurons that control the HPA axis, behavioral responses, and autonomic responses appropriate for the context into which they are placed [11]. The HPA axis, in particular, is a stressor-activated network that facilitates essential, body-wide adaptations to challenges by connecting hypothalamic neurons with the pituitary and, in turn, adrenal glands, which secrete stress hormones to maintain homeostasis. For HPA axis activation, the paraventricular nucleus of the hypothalamus $(\mathrm{PVN})$ is a critical regulatory node and is the final common pathway for the stress hormone responses. The PVN integrates multiple inputs from various upstream limbic regions which access the PVN trans-synaptically through neurons in the bed nucleus of the stria terminalis (BST) and peri-PVN region (see [3] for review). For the HPA axis, the PVN's output is ultimately coordinated by a group of neurons that synthesize a 41 amino acid peptide, corticotropin-releasing factor (CRF). CRFexpressing neurons send projections to the external zone of the median eminence where they can secrete CRF into the hypophyseal portal vasculature, thereby connecting the hypothalamus with cells in the anterior pituitary gland. CRF can then act upon corticotropinreleasing factor receptor 1 (CRFR1), a G-proteincoupled receptor found on corticotrophs, to allow the secretion of $\mathrm{ACTH}$ from the anterior pituitary gland into the general circulation. ACTH subsequently drives the adrenal secretion of GCs. Cortisol, the predominant GC in humans, and corticosterone (CORT), the predominant GC in rats and mice, can then act upon peripheral tissues to mobilize energy stores, induce lipolysis and proteolysis, and potentiate vasoconstriction driven by the autonomic nervous system (ANS), among myriad other effects. In addition, GCs have important actions within the central nervous system. Chronically elevated GCs can suppress reproduction and immune function and alter behaviors [11, 12]. Importantly, acute elevations in GCs that occur following stressors are thought to be beneficial and enhance cognition and metabolism and inhibit inflammatory responses. Together with the responses of the autonomic nervous system, these become detrimental with excess or chronic activation of the HPA axis. Chronic elevations in GCs have deleterious effects on neural function by decreasing the resilience of neurons and glia, thereby promoting neurotoxicity $[13,14]$. Such elevations are also associated with obesity, insulin resistance, and neurological disorders [5, 7]. Thus, understanding the factors regulating the HPA axis is important for ultimately controlling GC excess and disease risk.

\section{Sex differences in the HPA axis in rodents and humans}

Sex differences occur in the rodent's HPA axis response to stress, with females having a higher baseline level of CORT and a more robust CORT and ACTH response after exposure to a number of different types of acute stressors [15-18] (Fig. 1). Correspondingly, females have greater stress-responsive neuronal activity [18-20] and CRF gene expression in the PVN, as well as mRNA levels of the ACTH precursor proopiomelanocortin $(\mathrm{POMC})$ in the anterior pituitary [15, 17-19]. Additionally, female rats have a delayed return to baseline levels of ACTH and CORT after acute stress, suggesting sex differences in the negative feedback regulation of the HPA axis [15-18]. In limbic structures known to activate inhibitory inputs to the HPA axis, such as the frontal cortex and hippocampus, females have reduced neuronal activity compared to males following acute restraint [21]. Sex differences also exist in glucocorticoid feedback mechanisms that ultimately contribute to the less robust negative feedback on the HPA axis in females. Female rats have been shown to have lower hypothalamic glucocorticoid binding [22], reduced density of corticosteroid receptors in the pituitary [23], and lesser upregulation of hypothalamic corticosteroid receptor mRNA after acute stressors than do males [24]. Moreover, loss of forebrain [25] or PVN [26] GR results in HPA axis dysregulation in male but not female mice, suggesting that GR is less important for HPA regulation in females. Although the females used in these studies were not characterized according to stage of the estrous cycle, the data are consistent with that of Heck et al. [27] who later showed that negative feedback by glucocorticoid receptors is lacking in females in proestrus when estrogen levels are highest.

The availability of corticosteroids in brain regions where they can modulate HPA axis function may also influence their sex-dependent actions. While in the circulation, most corticosteroids are bound by corticosteroid-binding globulin (CBG), a liver glycoprotein [28]. At the target, 


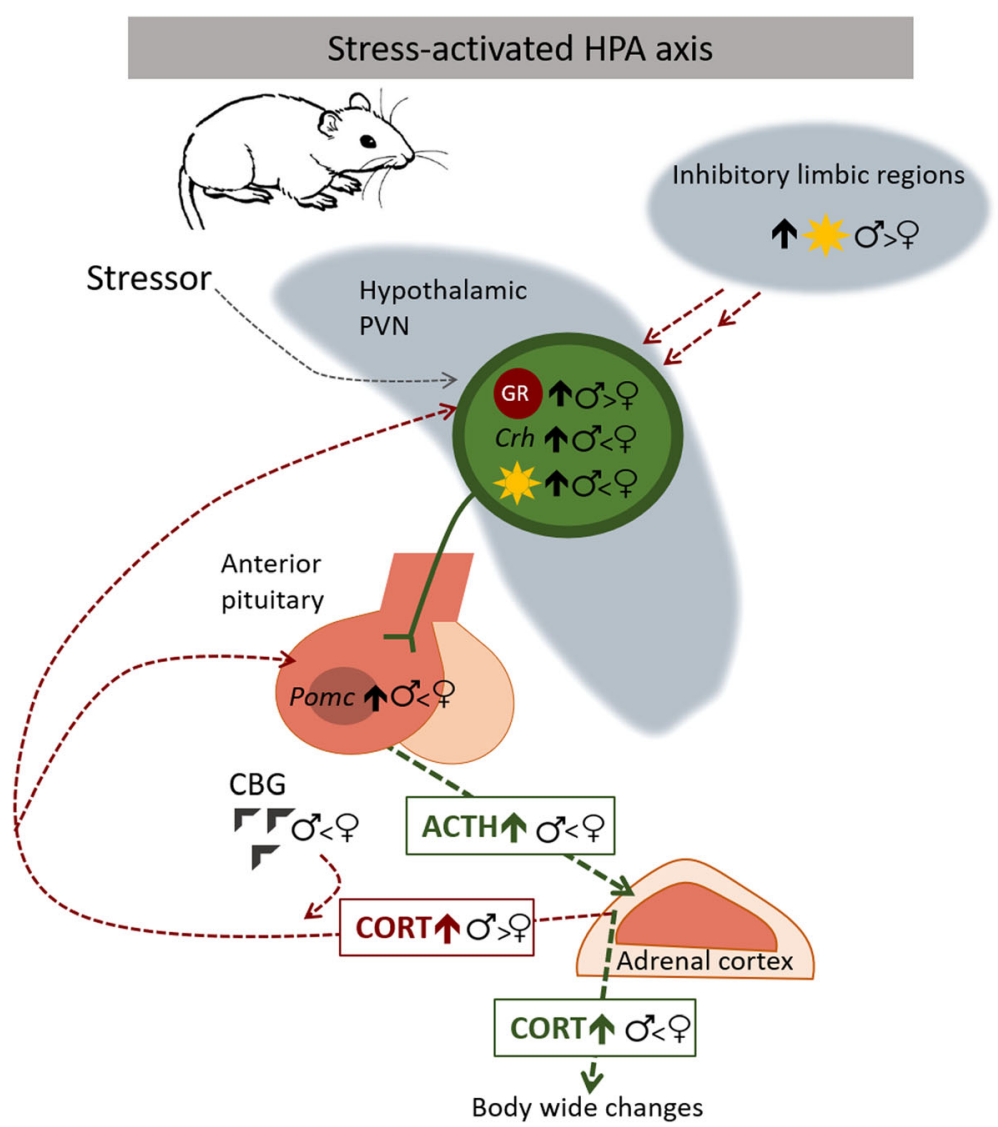

Fig. 1 Sex differences in HPA axis response to stress. Adult male versus female rodents have decreased HPA axis responses to acute stressors characterized by decreased paraventricular nucleus (PVN) neuronal activation and corticotropin-releasing hormone (CRH) gene expression, decreased pituitary expression of the proopiomelanocortin (POMC) precursor for adrenocorticotropin (ACTH), and decreased ACTH and corticosterone (CORT) responses to acute stressors. Males also have enhanced negative feedback (red arrow) resulting from their reduced corticosteroid-binding globulin (CBG) levels, their increased PVN glucocorticoid receptor (GR) gene expression, and their increased neuronal activation in limbic regions that inhibit the HPA axis. The sun symbol indicates neuronal activation

CBG releases corticosteroids (see [29] for review), since they can only bind the GR or MR when free from CBG [30]. Therefore, CBG levels can directly influence the activity of CORT by adjusting the available hormone to act upon target tissues. In females, basal CBG levels are almost twice those in males, yet levels of free CORT are not statistically different [31]. This raises the possibility that the higher levels of CBG may be buffering the higher total CORT in females [31, 32]. However, it is also possible that higher female CBG levels make them less responsive to negative feedback on the HPA axis following acute stress, as corticosteroids can only bind their receptors when free from CBG. In males, CBG is negatively regulated by acute stress, which makes CORT more available for negative feedback [33]. It is unknown if this is true in females. Thus, elevated CBG levels in females could make CORT less available for negative feedback and contribute to the enhanced HPA axis response to stress often reported in female rodents.

Notably, sex differences in the activity and regulation of the rodent HPA axis can depend on numerous factors, including strain and housing condition [34-39]. Nonetheless, most studies report that male rodents show a blunted HPA axis response to acute stress relative to females. In contrast, sex differences in the HPA axis are much less consistent in humans [40, 41]. While studies suggest that women have enhanced HPA responses to acute stressors compared to males, others indicate greater responses in males or no significant difference [40, 42-45]. These contradicting findings could be due to a number of factors, with stressor modality, age, health, and menstrual cycle stage of the participants being of importance [40, 42, 44].

\section{Sex differences in anxiety/depressive-like behaviors in humans and in rodents}

Dysregulation of the HPA axis (hypo- or hyperreactivity) is a hallmark of many stress-related diseases, which are known to differentially present in men versus women [40]. For instance, women are twice as likely to be diagnosed with depression and anxiety than are men [46-48], and subclinical symptoms of depression and 
anxiety are also more frequently reported in women [46-50]. Sex-related differences in HPA axis activity that may contribute to this sex difference are the focus of this review. However, the autonomic nervous system has also been implicated in mood disorders, and sex differences within its activity are an important area of research that requires further investigation [51].

Unlike in humans, sex differences in anxiety- and depressive-like behavior are inconsistently reported in rodents. Several studies in rats have reported that female rats show decreased anxiety-like behaviors, particularly in the elevated plus maze, compared to males [52-54]. In assays of depression-like behaviors, such as the forced swim test and sucrose preference test, female rats have also been demonstrated to show decreased despair-like behavior compared to males $[55,56]$. However, many other studies reported no sex differences in these behaviors (e.g., [57]) and some have reported decreased anxiety- and depressive-like behaviors in male rats [58]. In mice, sex differences in anxiety- and depressive-like behaviors are inconsistently reported [59, 60], and also similar to rats, the appearance of sex differences varies by genetic background as reflected by strain differences [59, 61, 62]. Sprague Dawley rats, for example, exhibit stable sex differences in immobility measures in a modified and extended version of the forced swim test, whereas a lack of sex differences was present in Long Evans rats across tests [63]. Similarly, housing environment can influence sex differences in affective behaviors in rodents [64, 65].

It is important to note however that behavioral assays for detecting anxiety or depressive-like behaviors in rodents were originally designed to screen potential anxiolytic and antidepressant compounds for activity and not for describing such behaviors in untreated animals. Thus, sex differences in such behavioral approaches may not provide an accurate assessment of basal mood state. It is also important to note that male and female rodents are reported to show differences in motivations underlying behaviors in anxiety-related tests such as the elevated plus maze. Factor analysis studies indicate that elevated plus maze behavior in male mice and rats is primarily motivated by anxiety, whereas behavior in females is primarily motivated by activity $[66,67]$. These studies suggest that interpretations of behaviors in anxiety-like assays might differ between males and females. Anxiety-like behaviors can also vary depending on estrous cycle phase in female rats, which is another important factor to consider when assessing sex differences in rodents [68].

The studies in rodents discussed above primarily involved assaying sex differences in anxiety- and depressive-like behaviors in rodents that had not been pre-exposed to prior stress. Importantly, select chronic stress models have been demonstrated to induce sex- specific effects on anxiety- and depressive-like behaviors, as well as HPA axis responses in mice. One such model is a sub-chronic variable stress (CVS) paradigm that involves exposure to varying stressors over a 6-day period [69]. This CVS model increases anhedonia-like behaviors in the sucrose preference test, increases anxiety-like behaviors in the novelty suppressed feeding task, and elevates CORT levels in female but not male mice [69, 70]. In contrast, other chronic stress paradigms, which are generally longer in duration and include greater stress severity, have yielded mixed results including greater behavioral disturbances in males or increased anxiety/ depressive-like behaviors in both sexes [71-73]. Collectively, these studies suggest that sub-chronic variable stress can induce sex differences in anxiety and depressive behaviors that are reflective of the human population (males < females), which is critical in terms of increasing translational value and for understanding mechanisms that might underlie female vulnerability or male resistance to stress-related disorders.

\section{A role for gonadal hormones}

While social, cultural, and experiential factors contribute to sex differences in anxiety and depression $[74,75]$, it is also clear that gonadal steroid hormones are a key contributing factor [76]. Sex differences in the prevalence of anxiety and depression develop after puberty [77]. Additionally, it has been postulated that the greater prevalence of depression in women $[46,78]$ is related to female-specific reproductive events marked by fluctuations in gonadal hormones, such as perimenstrual changes, pregnancy, the postpartum period, and menopause (see $[79,80]$ for review). Behavioral changes are also associated with hysterectomy, use of oral contraceptives, and use of testosterone therapy for reduced libido in women [81-83]. Furthermore, time-dependent exposure to stressors or glucocorticoid administration during development can influence the adult physiology of one sex more than the other in humans and animals [77] [84-89], supporting a role for perinatal and adult levels of gonadal hormones to alter adult risk for stress-related diseases.

As the cellular and molecular actions of estrogens and their effects on the HPA axis and stress-related behaviors are relatively well-defined, this review will focus on the androgen influences on stress hormone and behavioral responses to stress.

\section{Androgens regulate the HPA axis and stress- related behaviors} Activational actions of androgens on the HPA axis and stress-related behaviors

Androgens are generally thought to inhibit the activity of the HPA axis. Thus, removal of endogenous 
androgens by gonadectomy (GDX) in males increases stress-induced ACTH and CORT secretion, and T treatment has the opposite effects [19, 90, 91]. T modulates the HPA axis either through direct actions at ARs or via metabolism to other compounds that interact with ARs or ERs (see Fig. 2). Notably, the reduction of $\mathrm{T}$ to the more potent and non-aromatizable androgen, dihydrotestosterone (DHT), is necessary for its suppression of glucocorticoid secretion after stress [92]. Accordingly, inhibition of the enzyme that converts T to DHT, $5 \alpha$-reductase, with the central infusion of finasteride increases stressenhanced glucocorticoid secretion in male rats [92]. Consistent with these results, DHT placed near the PVN in adult, gonadectomized (GDX'd) male rats reduces the ACTH and CORT responses to acute stress [93].

An important point to consider is that most studies examining androgen effects on the HPA axis employ DHT, which has a very high affinity for ARs, and cannot be aromatized to E2 [94]. However, DHT has another interesting property in that it can be metabolized to $5 \alpha$ androstane- $3 \beta, 17 \beta$-diol ( $3 \beta$-diol), which has been shown to bind and activate estrogen receptor beta (ER $\beta)$ [94]. Like DHT and ER $\beta$ agonists, $3 \beta$-diol inhibits the HPA axis response to stress $[93,94]$. These data suggest that the inhibitory effects of DHT on HPA axis activity may be partially mediated by $3 \beta$-diol signaling through ER $\beta$ and emphasize the importance of considering the roles
ER $\beta$ may play in facilitating androgen regulation of the HPA axis. Another pathway through which androgens can potentially regulate the HPA axis is via conversion of $\mathrm{T}$ to $\mathrm{E} 2$ by the aromatase enzyme. E2 potently binds both estrogen receptor alpha $(E R \alpha)$ and $E R \beta$ and can modulate HPA function through actions at both receptors.

Androgens have also been repeatedly shown to reduce anxiety and depression symptomology. Anxiety and depression are elevated in hypogonadal men and aging men with low levels of $\mathrm{T}$ [95-98]. Androgen replacement in older men and hypogonadal men elevates mood and decreases depressive symptoms, indicating that low levels of androgens specifically contribute to the etiology of these disorders $[98,99]$. Furthermore, $\mathrm{T}$ has been shown to attenuate cortisol release in men [100]. The androgenic suppression of hypothalamic-pituitary-adrenal (HPA) axis responses may play a key role in decreasing susceptibility to develop anxiety and depression, since chronic high levels of glucocorticoids are a key contributor to the development of these disorders [101].

In rodent models, androgens and their metabolites have also been shown to modulate anxiety- and depressive-like behaviors [3, 102]. Male rats GDX'd as adults show increased anxiety- and depressive-like behaviors, and these effects are eliminated by supplementation with $\mathrm{T}$ [103-105]. Similar androgen effects on

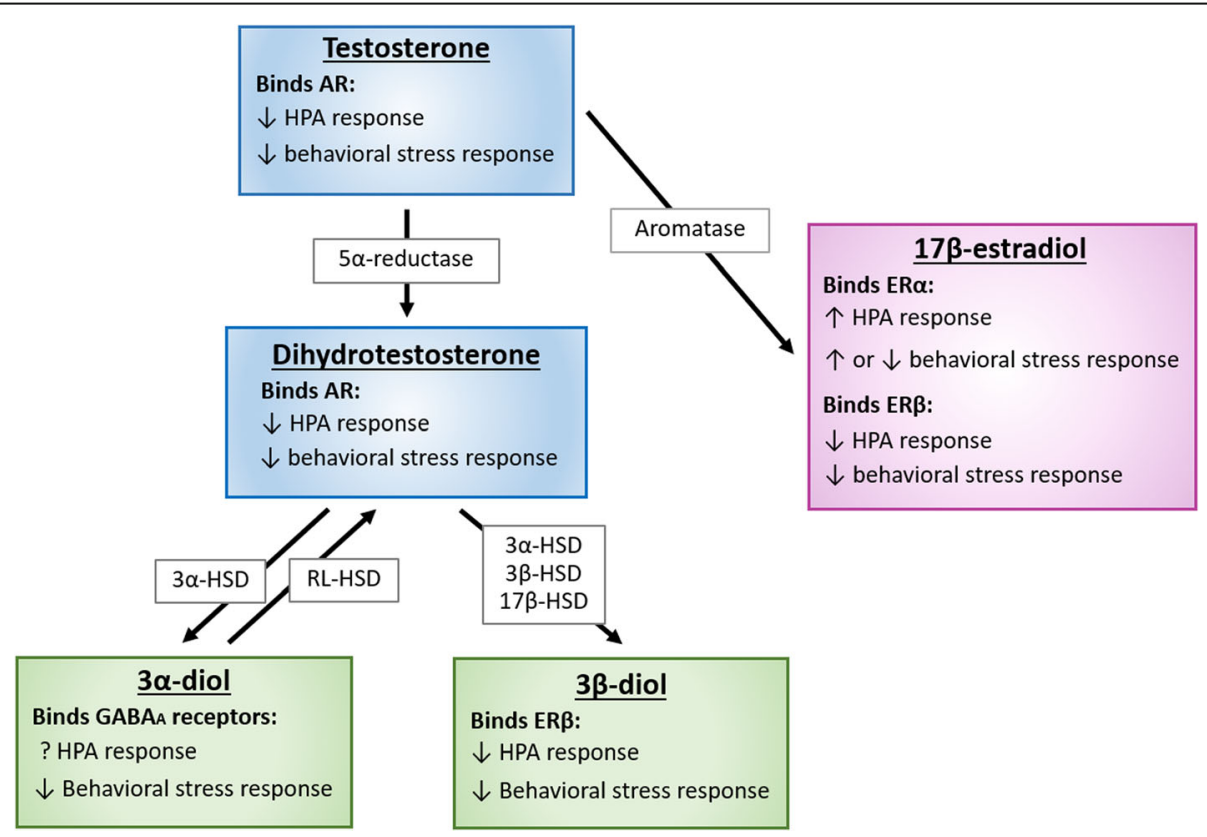

Fig. 2 Effects of testosterone (T) and its metabolites on HPA axis and behavioral stress responses. This figure describes enzymes involved in the conversion of $T$ and its metabolites and predicted effects produced by binding $A R, E R a$, $E R \beta$, and GABA receptors. Binding of $A R$ or $E R \beta$ is expected to decrease HPA axis and behavioral stress responses. In contrast, actions at ERa increase the HPA axis response to stress while effects on anxiety-like behaviors are mixed and depend on reproductive status among other factors. Effects of 3a-diol on the HPA axis are currently unknown. HSD = hydroxysteroid dehydrogenase; $3 a-D i o l=5 a$ androstane $3 a, 17 \beta$ Diol; $3 \beta$ Diol = 5a androstane 3 $\beta, 17 \beta$ Diol, RL-HSD = 11-cisretinol dehydrogenase like $3 a-H S D$ 
anxiety- and depressive-like behaviors have been reported in mice [70, 106-109]. Furthermore, procedures that increase endogenous $\mathrm{T}$ (e.g., exposure to females and female urine) also decrease anxiety-like behaviors $[110,111]$. Androgens have been shown to produce anxiolytic effects via metabolism of $\mathrm{T}$ to several different compounds including, but not limited to DHT, andro-

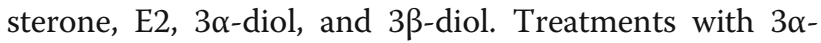
diol and E2 have both been demonstrated to produce anxiolytic effects in male mice in the open field and light-dark box test and anti-depressant effects in the forced swim test $[112,113]$. Furthermore, androsterone, DHT, and $3 \beta$-diol treatments have all been shown to reduce anxiety-like behavior in a variety of tests [111114]. These effects of $\mathrm{T}$ and its metabolites on both the HPA axis and behavioral stress responses are proposed to be mediated through ARs, ERs, and GABA receptors $[94,111]$.

\section{Organizational actions of androgens on the HPA axis and stress-related behaviors \\ Perinatal hormones}

Development of sex differences in rodents has largely been attributed to perinatal exposure to $\mathrm{T}$ that occurs only in males, particularly a prenatal surge in late gestation and a second surge that occurs immediately after birth $[115,116]$. These androgen pulses serve to either increase or decrease specific phenotypes of neurons in males [116, 117]. Typically, these effects occur following conversion of $\mathrm{T}$ to $\mathrm{E} 2$ by the aromatase enzyme and subsequent binding to ER $\alpha$ [115]. Humans, like rodents, are exposed to a gestational $\mathrm{T}$ surge which is proposed to regulate analogous sex differences in the human brain [117]. This differential exposure to gonadal hormones during development and adulthood alters brain structure and function and ultimately contributes to sexual dimorphisms in behavior and hormone release [117].

Gonadal hormone exposure around the time of birth has been shown to organize HPA axis functions in rodents [117]. Neonatal GDX in males increases basal and stress-induced CORT responses to stress in adult rats $[118,119]$. Additionally, a single injection of $\mathrm{T}$ in females on the day of birth decreases their adult HPA axis responses to stress [120] and reduces the amplitude and frequency of the pulsatile pattern of CORT secretion that is characteristic of female rats [120]. On the other hand, inhibition of the aromatase enzyme during the neonatal period in male rats increases stress-induced CORT and neural activation in stress-associated brain areas in adulthood [121]. This suggests that neonatal $\mathrm{T}$, likely via metabolism to E2 and interactions with ERs, suppresses adult stress reactivity.

Perinatal gonadal androgens have also been demonstrated to modulate adult anxiety-like behaviors although effects of androgens are commonly reported to be anxiogenic as opposed to generally anxiolytic effects found following adult treatments. Treatment of pregnant rats with $\mathrm{T}$ from gestational day 15 to 19 increased anxiety-related behaviors in offspring in the elevated plus maze, and this effect was strongest in females [122]. Furthermore, neonatal $\mathrm{T}$ treatment in female mice increases anxiety-like behaviors in the marble burying task, although it did not affect depressive-like behaviors in the tail suspension test [109]. Similarly, neonatally GDX'd male rats show decreased anxiety-like behaviors in several assays including the open field test, light-dark box, and elevated plus maze compared to mice that remained gonadally intact during the neonatal period $[118,123]$.

\section{Pubertal hormones}

Increases in circulating gonadal steroids occur at puberty and can provide another organizing signal to drive permanent changes in brain function. Accordingly, some evidence suggests that puberty represents a second critical period during which organizational actions of gonadal hormones can further influence the HPA axis [124]. Pubertal gonadal hormones modulate the neural and behavioral changes that ultimately produce adultlike characteristics [124], including changes in stress hormone responses. Prepubertal rats of both sexes have greater glucocorticoid responses to acute stressors compared to their responses in adulthood $([125,126]$ for review see [127]). $T$ exposure during both the prepubertal and perinatal period is important for the masculinization of HPA responses to stress in adulthood [109]. Pubertal $\mathrm{T}$ exposure is thought to organize the adult male-typical sensitivity of the HPA axis to androgen regulation [128]. Unlike males GDX'd in adulthood, adult male rats that were GDX'd before puberty do not respond to T administration with decreases in basal or stress-induced PVN gene expression or glucocorticoid secretion [128]. Thus, puberty represents a potential critical organizational period during which rising levels of androgens play an important role in sculpting the correct development of a male-typical, androgen-sensitive adult HPA phenotype (for review, see [102]).

Pubertal elevations in E2 may also play an important, although less pronounced, role in the organization of the adult HPA axis. Before puberty, E2 decreases HPA axis activity in female rats, whereas in adulthood it increases HPA activity [129]. Interestingly, this change in the HPA response to E2 does not appear to depend on prepubertal elevations in ovarian steroids [129]. In adult females, E2 treatment increases basal and stress-induced CORT secretion regardless of whether they were ovariectomized before or after puberty [129]. Thus, unlike that for androgens, pubertal E2 exposure is not essential for 
establishing the stimulatory effects of E2 on the HPA axis in adult females.

Gonadal hormones during puberty also regulate stressrelated behaviors, although effects appear to be species specific. In rats, GDX in males prior to or near the onset of puberty has been shown to decrease anxiety-related behaviors in the open field, elevated plus maze, and light-dark box [130, 131]. These results are similar to those found in rats GDX'd in the neonatal period and raise the possibility that puberty rather than the neonatal period might be the critical phase for gonadal hormone organization of anxiety-like behaviors; however, further experiments that involve hormone manipulations at both periods are necessary to assess this possibility $[118,123]$. In contrast to rats, pre-pubertal GDX in male mice increases, while pre-pubertal GDX in females decreases, anxiety-like behaviors [132, 133]. Together, these studies suggest that pubertal gonadal hormones contribute to the organization of anxiety-like behaviors, although the direction of effects differs by species in rodents.

\section{Gonadal steroid hormone receptors involved in androgen effects on the HPA axis and anxiety/ depressive behaviors \\ Androgen receptor \\ HPA axis}

As mentioned above, $\mathrm{T}$ and DHT have been well established as potent suppressors of the HPA axis [16, 90]. Furthermore, antagonism of AR with flutamide or finasteride increases CORT responses to stress [92, 134]. However, both $\mathrm{T}$ and DHT can be further converted to compounds that bind estrogen, GABA, and other receptors $[94,135,136]$. Therefore, studies performed in ARdeficient rodents in the past decade have been vital in confirming a critical role of AR in suppressing HPA axis reactivity $[106,108,137,138]$. In a series of studies performed in mice and rats with the spontaneously occurring testicular feminization mutation (Tfm), which renders the AR largely non-functional, Tfm males demonstrated increased CORT responses to stress compared to wild types $[106,138]$. It is important to note that the $\mathrm{Tfm}$ rat has elevated $\mathrm{T}$ levels compared to wild-type mice [139], yet still shows an elevated CORT response to stress, providing further evidence that AR is necessary for androgen suppression of the HPA axis. The role of AR in HPA axis regulation has been further supported in experiments utilizing a Cre-lox AR knockout mouse line (iTfm). Both basal and stress-induced (light-dark box) CORT levels are elevated in T-treated iTfm mice compared to similarly treated wild-type mice [108].

\section{Anxiety/depressive-like behaviors}

Actions of $\mathrm{T}$ and its metabolite DHT have been shown to produce anxiolytic effects via actions at the AR.
Treatment with flutamide reduces the anxiolytic effects $\mathrm{T}$ in orchidectomized rats [114]. Studies involving various lines of AR-deficient mice and rats further support the role of AR in influencing anxiety- and depressivelike behaviors. Both mice and rats with the Tfm mutation show increased anxiety-like behaviors in several assays $[106,138,140]$. Similar findings of increased anxiety-like behavior are reported in the iTfm model [108]. A recent study also indicates that the male resilience to exhibit anhedonia-like behavior following subchronic variable stress is regulated by $\mathrm{T}$ [70]. Furthermore, depressive-like symptomology is enhanced in ARdeficient mice exposed to chronic mild stress [141]. Together, these studies indicate a robust role of androgen acting via AR in influencing anxiety- and depressive-like behaviors in rodents. Studies in humans also indicate that androgen actions through the AR are beneficial to mood, since treatment with flutamide in prostate cancer patients increases depressive symptoms [142, 143]. Furthermore, individuals with complete androgen insensitivity syndrome, who have dysfunctional AR, are reported to show high rates of depression ( 36\% incidence [144]; ) and AR is decreased in the PVN of depressed patients [145].

\section{Anatomical sites of action for AR effects on the HPA axis and stress-related behaviors}

Androgens have been suggested to act via AR at the levels of the pituitary and adrenal glands to modulate the HPA axis. AR knockout mice show increased POMC mRNA and decreased GR in the pituitary as well as hypertrophic adrenal glands [146]. However, the possibility that AR knockout results in changes at the PVN level, which in turn lead to this increased POMC mRNA and adrenal hypertrophy, cannot be excluded. Accordingly, there is strong evidence that $\mathrm{T}$ acts via AR centrally within the brain to regulate the HPA axis, since inhibitory effects of androgens on ACTH and CORT release are blocked by administration of the 5 -alpha reductase inhibitor, finasteride into the 3rd ventricle [92].

Several brain regions have been implicated as potential sites at which androgens might interact with AR to regulate the HPA axis and anxiety- and depressive-like behaviors. A study comparing expression of the immediate early gene c-Fos in the brains of $\mathrm{Tfm}$ and wild-type rats subjected to an open field stress revealed differing neural activation patterns in the dentate gyrus, medial preoptic area, and medial amygdala, suggesting these as sites at which actions at AR might mediate stress functions [138]. However, more evidence indicates the BST or PVN as sites for such actions. The BST contains very high levels of AR within nearly all subdivisions in rodents $[147,148]$. AR-containing cells in the BST project to the parvocellular PVN and thus have been proposed 
as a site at which androgens can regulate HPA axis reactivity $[149,150]$. The BST is also well known to play a key role in influencing anxiety-related behaviors and has been suggested as a critical brain site for mediating sex differences in anxiety and depression [151]. The PVN, on the other hand, contains moderate levels of AR. While few CRH-containing neurons co-express AR [27, 152], there is evidence that AR acts outside these neurons, but still within the PVN, to influence HPA activity [27, 153-155]. Additionally, although the PVN has historically been associated with regulating neuroendocrine and autonomic functions, it has become clear that this region also controls behavioral responses to stress [156]. Thus, the PVN, like the BST, is a likely site at which actions at AR influence the HPA axis and stress-related behaviors.

\section{Estrogen receptor alpha HPA axis}

Another potential mechanism for androgen regulation of the HPA axis is through conversion of T to E2 and subsequent binding to ER $\alpha$. In contrast to the inhibitory role of AR, binding to ER $\alpha$ activates the HPA axis. Stimulation of ER $\alpha$ using the selective agonists propylpyrazoletriol (PPT) and moxestral increases stressinduced ACTH and CORT in male and female rats [93, 157]. ER $\alpha$ has also been shown to play a key role in diminishing negative feedback on the HPA axis. Administration of PPT impairs the ability of dexamethasone to suppress the diurnal rise and restraint stress-induced release of ACTH and CORT [158]. It is important to note that while androgens are capable of producing these effects via further metabolism and binding of ER $\alpha$, systemic $\mathrm{T}$ generally suppresses stress-induced HPA axis responses and increases negative feedback on the HPA axis $[16,159]$. This suggests that interactions with other gonadal steroid hormone receptors might negate or diminish any HPA axis enhancing effects of ER $\alpha$.

\section{Anxiety/depressive-like behaviors}

Actions through ER $\alpha$ have commonly been shown to produce anxiogenic effects in rodents. This anxietyenhancing role of $E R \alpha$ is supported by studies involving pharmacological stimulation of ER $\alpha$ with PPT, which has been shown to increase anxiety-like behaviors [157, 160]. However, the role of ER $\alpha$ remains somewhat unclear [160-162], as both anxiogenic and anxiolytic effects of PPT that depend on the reproductive experience of females $[163,164]$ have been reported, and few investigations of ERo's role in stress responsivity have been performed in males [160]. Interestingly, discrepant effects of global ER $\alpha$ deletion have been reported in male and female mice. For example, deletion of ER $\alpha$ fails to alter anxiety-like behaviors in females [165] but increases anxiety-like behaviors in males [166]. This indicates that in males, ER $\alpha$ binding might normally reduce anxiety-like behaviors. However, this interpretation is complicated, and both organizational and activational roles of ER $\alpha$ in influencing these behaviors need to be considered since ER $\alpha$ is absent in ER $\alpha$ knockout mice throughout the lifespan. In human populations, specific variants of the ER $\alpha$ gene have been repeatedly associated with anxiety and depression disorders [167-169]. This indicates that ER $\alpha$ might also be a key receptor through which sex steroid hormones can affect anxiety/mood disorders in humans.

\section{Anatomical sites of action for ERa effects on the HPA axis and stress-related behaviors}

Given that there are few ER $\alpha$ expressing cells in the rat PVN [170], and only modest levels in the mouse PVN [171], one key site implicated in regulating the HPA axis enhancing effects of ER $\alpha$ is the peri-PVN. The peri-PVN is located just dorsal and lateral to the PVN and contains high levels of ER $\alpha[172,173]$. Infusion of PPT into the peri-PVN in rats suppresses dexamethasone-induced negative feedback on the HPA axis and increases psychological stress-induced c-Fos within the PVN [158]. These findings indicate that peri-PVN ER $\alpha$ is critical for central regulation of HPA axis function. The peri-PVN is primarily comprised of GABAergic neurons, thus actions at peri-PVN ER $\alpha$ are predicted to decrease inhibitory tone to PVN HPA controlling neurons, thus increasing HPA axis activation [3].

In general, the neuroanatomical sites within which $E R \alpha$ can induce effects on stress-related behaviors are largely obscure, although the nucleus accumbens, preoptic area, hypothalamus, and amygdala have been suggested [3, 174-176]. Furthermore, ER $\alpha$ has been shown to have opposing effects, both increasing and decreasing anxiety- and depressive-like behaviors depending on the brain region in which it is located. Downregulation of $\mathrm{ER} \alpha$ in the medial preoptic area and posterodorsal amygdala decreased anxiety-like behavior suggesting an anxiogenic role of ER $\alpha$ in these regions $[175,176]$. In contrast, ER $\alpha$ overexpression in the nucleus accumbens induces anti-depressant-like effects and stress resilience in male and female mice pre-exposed to chronic stress [174]. These region-specific, opposing actions on stressrelated behaviors may contribute to discrepant findings involving systemic PPT administration and global deletion of ER $\alpha[160,165,166]$.

\section{Estrogen receptor beta HPA axis}

Androgens can interact with ER $\beta$ via conversion of $T$ to E2 by the aromatase enzyme. Furthermore, the 5-alphareduced $\mathrm{T}$ metabolite DHT can be further converted to 
$3 \beta$-diol, which has a high affinity for ER $\beta$ [177], but very low affinity for AR [178]. Numerous studies in rodents indicate an HPA axis-suppressing role of ER $\beta$. Administration of the ER $\beta$ agonist DPN attenuates stressinduced increases in $\mathrm{ACTH}$ and CORT in male and female mice and rats $[93,157,158,179]$, while DPN produces no effects in ER $\beta$ knockout mice [179]. Studies in GDX'd males also indicate that administration of the androgen metabolite $3 \beta$-diol attenuates stress-induced ACTH and CORT [93, 180]. Furthermore, coadministration of the ER antagonist tamoxifen to DHTtreated mice partially blocks the inhibitory effects of DHT on ACTH and CORT responses [93]. It is proposed that this partial inhibition occurs via blockade of $3 \beta$-diol actions at ER $\beta[3,93]$.

\section{Anxiety/depressive-like behaviors}

In contrast to ER $\alpha$, actions at ER $\beta$ have primarily been shown to induce anxiolytic effects. ER $\beta$ knockout female mice show increased anxiety-like behaviors, although these behaviors were not altered in ER $\beta$ knockout males [165]. Furthermore, administration of the ER $\beta$ agonists DPN and WAY-200070 reduces anxiety-like behavior in male and female rodents in a variety of tests including the open field test and elevated plus maze [157, 158, 179]. Again, the likely mechanism through which androgens might decrease anxiety-like behaviors via actions at ER $\beta$ is through conversion of DHT to $3 \beta$-diol and subsequent binding of ER $\beta$. Administration of $3 \beta$-diol has been shown to decrease anxiety-like behavior in the elevated plus maze [181], and this effect is dependent on the presence of functional ER $\beta$, since $3 \beta$-diol fails to produce an anxiolytic effect in ER $\beta$ knockout mice [182]. Fewer studies have investigated a role of ER $\beta$ in influencing depressive-like behaviors; however, a recent report suggests a sex-specific role of ER $\beta$ in regulating stressinduced anhedonia. Male ER $\beta$ knockout mice show decreased sucrose preference in response to inescapable footshock, while preference in females was unaffected [183]. Evidence in humans for a potential role of ER $\beta$ in stress-related behaviors is quite limited in comparison with rodent literature. Two studies reported that AA alleles of Esr2 rs1256049 and rs4986938 were associated with an increased incidence of generalized anxiety disorder and major depression, respectively, in women $[168,184]$. However, the role of Esr2 variants in men, and the contribution of the role of androgens, is poorly understood.

\section{Anatomical sites of action for ER $\beta$ effects on the HPA axis and stress-related behaviors}

One potential key site for ER $\beta$ modulation of the HPA axis is the PVN, which expresses very high levels of ER $\beta$ in both rats and mice [171, 173, 185, 186]. Implantation of DPN near the PVN in male rats attenuates stressinduced ACTH and CORT and c-Fos expression in the PVN [93], similar to peripheral injections of DPN [157]. Importantly, the PVN contains the key enzymes needed for metabolism of androgens to ER ligands including aromatase, $5 \alpha$-reductase, $17 \beta-\mathrm{HSD}, 3 \alpha-\mathrm{HSD}$, and cytochrome p450 7b (CYP7B) $[93,187]$. ER $\beta$ may also directly regulate HPA axis activation, as neuropeptideexpressing PVN neurons known to modulate HPA activity co-express ER $\beta[171,188][171,185,188,189]$. Alternatively, the BST also contains high levels of ER $\beta$ and might be a key site for ER $\beta$ regulation of the HPA axis based on its known role in modulating HPA axis tone $[3,186]$.

One ER $\beta$-rich region, the dorsal raphe nucleus, has also been proposed as a potential key site for influencing stress-related behaviors [190]. Dorsal raphe serotonin neurons exhibit high co-expression with ER $\beta$ in rats [191] and non-human primates [192]. There is strong evidence that estrogen actions through ER $\beta$ can regulate the serotonin system by modulating levels of tryptophan hydroxylase, the enzyme required for serotonin synthesis. Ovariectomy decreases, while supplementation with the ER $\beta$ agonist LY3201 increases, dorsal raphe tryptophan hydroxylase [193]. Placement of DPN near the dorsal raphe can increase TPH2 mRNA expression and also increase active stress-coping behaviors in the forced swim test [191]. Furthermore, tryptophan hydroxylase is decreased in the brains of ER $\beta$ knockout male and female mice [193]. Castration in males has also been shown to decrease dorsal raphe serotonin synthesis while supplementation with $\mathrm{T}$ increases synthesis $[194,195]$. Therefore, androgen metabolites might also induce effects on dorsal raphe serotonin neurons by binding ER $\beta$, although this has not been directly tested. A recent study revealed that injections of DPN into the dorsal raphe reduced anxiety-like behaviors in food-restricted female rats, further implicating this as a key site of action for influencing behavioral stressresponses in rodents [196]. However, in non-foodrestricted female rats, dorsal raphe administration of DPN failed to alter anxiety-like behaviors [191]. The potential role of androgens in this process is largely unclear, in part due to the absence of similar studies performed in males. Alternative sites for ER $\beta$ 's effects on stress-related behaviors are the PVN, BST, and medial amygdala given the high expression of ER $\beta$ and known role of these regions in influencing behavioral stress responses $[156,165,172$, $179,186]$.

\section{Gonadal hormone receptor signaling}

$A R, E R \alpha$, and ER $\beta$ all belong to the same family of receptors, nuclear receptor subfamily 3 , and all receptors in this subfamily function classically as ligand-activated transcription factors [197]. They reside as multi-protein 
complexes in the nucleus or cytoplasm until ligand binding initiates their shuttling to chromatin DNA. To alter transcription, these receptors can bind directly to hormone response elements on DNA and/or interact with other transcriptional regulators [198, 199]. Notably, ERs and ARs can also be found as membrane receptors that have faster (non-classical) influences on neuronal function and/or transcriptional activity by modulating second messenger pathways and ion channels [200, 201]. Although androgen's non-classical membrane actions were thought to largely occur through aromatization to E2, there is emerging evidence that $\mathrm{T}$ and/or its metabolites may act directly at membrane receptors. For example, $3 \alpha$-diol has high affinity for GABA/benzodiazepine receptors [200], and actions at these receptors can decrease anxiety-like behavior (reviewed in [202]). In terms of the HPA axis literature, studies examining nongenomic gonadal steroid signaling are largely missing. However, there is evidence that E2 binds to a G-proteincoupled ER to desensitize serotonin signaling in the PVN and reduce activation of the HPA axis [203, 204].

\section{Role of neuropeptide systems in androgen regulation of stress}

Studies spanning the last three decades have demonstrated a clear role for androgens in modulating neuropeptide systems that control the HPA axis and behavioral stress responses. In this section, we review androgen regulation of three key neuropeptide systems: CRF, arginine vasopressin (AVP), and oxytocin, and their cognate receptors.

\section{Corticotropin releasing factor}

Corticotropin-releasing factor (CRF) signaling through pituitary CRFR1 is well established as critical for controlling the HPA axis [205]. CRF release and subsequent binding to brain cognate CRFR1 and CRFR2 receptors have also been repeatedly shown to regulate stressassociated behaviors as well as to modulate HPA axis tone $[205,206]$. Genetic deletion or antagonism of CRFR1 suppresses the release of ACTH and CORT and decreases anxiety- and depressive-like behaviors [207209], while CRFR1 stimulation produces opposite effects [210]. In contrast, genetic deletion of CRFR2 produces effects opposite to those of CRFR1 deletion, increasing anxiety-like behaviors and HPA responses to stress [211, 212]. These studies and others suggest opposing actions of CRFR1 and CRFR2 whereby CRFR1 binding increases activation of the HPA axis and anxiety-related behaviors while CRFR2 attenuates these responses.

Androgens have been demonstrated to produce brain region-specific alterations in CRF and both receptor phenotypes. Androgens are able to induce these effects due to the presence of androgen and estrogen response elements (AREs, EREs) in the promotor region of CRF and its cognate receptors [213-215]. Immunohistochemical studies also indicate that select groups of CRF and CRFR1 expressing neurons co-express androgen and estrogen receptors $[27,155,171,216]$. For example, neurosecretory PVN CRF neurons are reported to show moderate co-expression of ER $\beta$ in both rats and mice [171, 188]. Additionally, while few CRF neurons coexpress AR [27, 152], the majority of CRFR1-containing cells in the PVN co-express AR [155]. In the BST, a high percentage of CRF neurons also co-express AR [27]. Furthermore, CRFR2 and AR distributions show extensive overlap in the brain [217].

Several studies indicate that androgens can regulate CRF levels in the adult rodent brain. Bingaman et al. [218] demonstrated that CRF cell number in the PVN increased 3 weeks after GDX in males and treatment with DHT reversed this effect. Furthermore, restraintinduced elevations in PVN CRF hnRNA are reduced in GDX'd males supplemented with DHTP [180]. CRF mRNA levels are also reported to decrease in castrated male rats within the fusiform nucleus of the BST, and again, levels are restored following androgen supplementation [219]. An opposite effect of androgens on CRF occurs in the dorsolateral BST which contains a greater number of CRF neurons in female than male mice and rats $[220,221]$. In the dorsolateral $\mathrm{BST}$, castration decreases CRF levels in males [220]. Neonatal androgens have also been reported to alter adult levels of CRF. Specifically, treatment with the anti-androgen flutamide during the neonatal period increases CRF mRNA in the PVN of lipopolysaccharide-injected adult rats [222]. Furthermore, neonatal $\mathrm{T}$ treatment in female rats decreases the number of CRF-expressing cells within the dorsolateral BST in adulthood [223].

Sex differences have been reported in various brain regions for CRFR1 and CRFR2 (e.g., [155, 216, 224, 225]), and androgens have been demonstrated to play a role in regulating these sex differences in select brain areas. For example, CRFR1 levels are greater in the male compared to female PVN, and GDX in males decreases CRFR1 to levels similar to females [27, 155]. CRFR2 has also been shown to be upregulated by androgens in several brain regions. Treatment with DHTP increases CRFR2 mRNA levels within the lateral septum, hypothalamus, and hippocampus [226]. Altogether, these findings reveal that androgens affect the CRF system in a manner that is predicted to suppress the HPA axis response as well as anxiety- and depressive-like behaviors. For instance, high levels of PVN CRF are associated with hyperactivation of the HPA axis, whereas PVN CRFR1 has been shown to actively inhibit CRF neurons, thereby suppressing HPA axis function [153, 154]. Androgeninduced decreases in CRF and increases in CRFR1 would 
therefore be expected to diminish the HPA axis response. Furthermore, androgen-induced increases in CRFR2 might likely produce an anxiolytic effect given the known role of CRFR2 in reducing anxiety-related behaviors $[211,212]$.

\section{Arginine vasopressin}

Arginine vasopressin (AVP) is produced in neurons in several brain regions including PVN, supraoptic nucleus, BST, and medial amygdala (MeA). Central release of AVP has been demonstrated to affect a wide range of behaviors including those associated with anxiety and depression [227]. AVP is also critical to HPA axis regulation; AVP released from the PVN acts in conjunction with CRF to potentiate the release of ACTH [228].

Several sex differences in the AVP system have been reported in rodents, including a greater number of cells expressing AVP in the male BST and MeA as well as a greater AVP fiber density in the lateral septum of males [229-231]. In contrast, AVP cell number in the PVN is commonly reported as similar between the two sexes [232], although within-sex studies have demonstrated that gonadal steroid hormones can regulate PVN AVP levels [150, 219, 233, 234]. Treatment of GDX'd males with E2 decreases PVN AVP mRNA in wild type, but not ER $\beta$ knockout mice, suggesting that this suppressive effect of estrogen is mediated through ER $\beta$ [233]. In rats, estrogens have been shown to regulate PVN AVP immunoreactivity in females [234]. Studies in male rodents also suggest a role of androgens in regulating PVN AVP. Implants of DHT into the posterior BST increase AVP mRNA in the PVN, while co-treatment with the anti-androgen, hyroxyflutamide, eliminates this effect [150]. Furthermore, GDX attenuates the rise in PVN AVP that occurs in response to adrenalectomy, while T or DHT replacement restores the elevated AVP response [219]. Since AR is largely absent in AVP neurons of the PVN, it has been proposed that androgens might act remotely in regions such as the BST to regulate AVP in the rat PVN [149, 150, 235]. However, AVP neurons in the PVN co-express ER $\beta$ indicating that androgen metabolites can directly act on these neurons [189, 236, 237].

Androgens potently regulate the sexually dimorphic distributions of AVP neurons and fibers. Long-term GDX in male rats ( 15 weeks) virtually eliminated cell bodies for AVP in the BST and MeA [238]. Accordingly, fiber density in the lateral septum was also diminished, since AVP fiber innervation to this area originates from the BST and MeA [229]. Subsequent studies indicate that $\mathrm{T}$ actions at both estrogen and ARs are necessary for masculinization of these structures. A series of studies performed by De Vries, Wang, and colleagues demonstrated that E2 increased AVP mRNA in the BST and
MeA and a combined E2 + DHT treatment induced a further increase $[239,240]$. AVP neurons in both regions highly co-express both AR and ERs indicating the presence of receptors through which E2 and DHT can produce these effects [235, 241]. Exogenous $T$ treatment has also been shown to cause DNA hypomethylation of the AVP promoter in the MeA and BST [242] and in vitro studies identified $E R \beta$ binding to $3 \beta$-diol as a potential regulator of the AVP 5'untranslated region [243].

Fewer studies have investigated effects of androgens on AVP receptors (V1a, V1b, V2), and investigations in mammals have been primarily performed in hamsters with a focus on the V1a receptor (see [244] for review). Studies in Syrian hamsters indicate that castration decreases V1a receptor binding in the MPOA, ventromedial hypothalamus, and BST [245, 246]. Furthermore, androgens have been reported to increase V1a receptor mRNA in the medial preoptic area of Syrian hamsters [246]. However, studies in rats have failed to provide evidence for gonadal steroid hormone regulation of V1a [247, 248], indicating species differences in androgen sensitivity to effects on AVP and its receptors.

With regard to behavior, alterations in these AVP systems have primarily been linked to androgen-related modifications in social and aggressive behaviors [230, 244]. However, androgen-dependent changes in central AVP also have implications for modifying the HPA axis and stress-related behaviors. For instance, AVP release into the lateral septum has been shown to reduce immobility in rats in the forced swim test while infusion of a V1 antagonist into the same region produces opposite effects [249]. Since AVP innervation of the lateral septum is androgen regulated, this might be a mechanism through which androgens can modulate depressivelike behaviors.

\section{Oxytocin}

Oxytocin has been repeatedly shown to reduce activation of the HPA axis and suppress anxiety-like behaviors [250-252]. Intracerebroventricular administration of oxytocin attenuates $\mathrm{ACTH}$ and CORT responses to stress, decreases anxiety-like behaviors, and decreases neural activation in the PVN [252-254]. Conversely, antagonism of the oxytocin receptor increases anxiety-like behaviors and HPA axis responses to stress [250, 255]. Oxytocin knockout models also reveal hyperactivation of the HPA axis after stress, further confirming the HPA axis-suppressing role of oxytocin signaling [256].

Oxytocin neurons in the PVN highly co-express ER $\beta$ but not ER $\alpha$ in the human and rodent PVN [171, 185, 188]. AR is also co-expressed within oxytocin neurons in the medial parvocellular division of the PVN (mpvPVN) but not in magnocellular oxytocin neurons in rats [235]. In humans, oxytocin/AR co-labeled neurons are also 
found in the PVN [257] and T treatment of a human neuroblastoma cell line reduces oxytocin mRNA through an AR-mediated mechanism [257]. Together these studies indicate the potential for androgens and their metabolites to regulate expression and function of PVN oxytocin neurons. E2 treatment increases oxytocin mRNA in the mouse PVN [233, 258]. Furthermore, these effects of E2 are dependent on ER $\beta$ since oxytocin mRNA levels are unaffected by E2 treatment in ER $\beta$ knockout mice [233, 258]. Since DHT can be converted to $3 \beta$-diol, which has high affinity for ER $\beta$, this might be a pathway through which androgens can alter oxytocin expression. Evidence for this is reported by Sharma et al. [259] who utilized a mouse hypothalamic cell line which expresses both ER $\beta$ and oxytocin and found that treatment with the T metabolite $3 \beta$-diol, as well as DPN and E2, increased oxytocin mRNA levels. Further support for $3 \beta$-diol regulation of the oxytocin promoter comes from studies by Hiroi et al [260] who demonstrated that $3 \beta$ diol can activate the human oxytocin promoter through ER $\beta$ in a fashion that is consistent with the presence of a composite hormone response element in the 5 ' untranslated region.

Gonadal steroid hormones have also been shown to induce changes in oxytocin receptor binding in rodents. For example, castrated rats treated with testosterone propionate (TP) show 4-5-fold increases in oxytocin binding in the BST and ventromedial hypothalamus [261]. E2 treatment also increases oxytocin receptor binding in the ventromedial hypothalamus and medial amygdala of rats and mice [258, 262]. Gonadal hormone regulation of oxytocin receptor in the ventromedial hypothalamus and medial amygdala appears to be primarily mediated by ER $\alpha$, rather than ER $\beta$, since E2 increases oxytocin receptor binding in ER $\beta$ knockout mice [258]. Together, these studies provide evidence that androgens can potentially mediate levels of oxytocin and receptor binding following metabolism to estrogenic compounds. Additionally, an oxytocin antagonist can block some of the effects of the ER $\beta$ agonist DPN on anxiety-like behaviors [263]. Thus, the HPA axissuppressing and anxiety-reducing effects of oxytocin might be modulated through these mechanisms.

\section{Perspectives and significance}

As described in this review, androgens play a key role in influencing the HPA axis and anxiety- and depressivelike behaviors and, accordingly, contribute to sex differences in these functions. Although substantial work has been done to determine the androgen metabolites and receptor subtypes involved in modulating the HPA axis and behavioral stress responses [3], questions remain regarding critical periods during which androgens act to produce these effects. Another key question remains with regard to the specific cell phenotypes and anatomical regions involved in androgen effects on these responses. Important to consider are the potentially opposing hormonal and behavior effects induced by androgen and androgen metabolites acting within different areas. Determining the precise sites of action that regulate these functions is difficult given the widespread distribution of gonadal steroid hormone receptors (e.g., AR, $E R \alpha$, and $E R \beta$ ) in numerous brain regions known to regulate stress responses [147, 172, 186]. Regardless, several brain regions have thus far been indicated as key central sites of actions including the PVN, peri-PVN, BST, dorsal raphe, hippocampus, and nucleus accumbens $[3,70,174]$. Furthermore, key cell phenotypes including those that produce or contain receptors for CRF, AVP, and oxytocin appear critical for the influence of androgens on the HPA axis and stress-related behaviors. Future studies that utilize contemporary viral and genetic strategies will be key in elucidating the precise mechanisms through which androgens regulate stress responses. Uncovering these mechanisms will thus provide essential insight toward understanding how sex hormones contribute to sex disparities stress-related mental illnesses including anxiety and depression.

\section{Abbreviations \\ 3a-Diol: $5 a l p h a$ androstane $3 a, 17 \beta$ diol; $3 \beta$-Diol: 5 alpha androstane $3 \beta, 17 \beta$ diol; $17 \beta$ HSD: $17 \beta$ Hydroxysteroid dehydrogenase; \\ ACTH: Adrenocorticotrophic hormone; ANS: Autonomic nervous system; AR: Androgen receptor; ARE: Androgen response element; AVP: Arginine vasopressin; BST: Bed nucleus of the stria terminalis; CBG: Corticosteroid- binding globulin; CORT: Corticosterone; Cre: Cre recombinase; \\ $\mathrm{CRH}$ : Corticotropin-releasing hormone; CRFR1: Corticotropin-releasing factor receptor 1; CVS: Chronic variable stress; CYP7B: Cytochrome p450 7b; \\ DHT: Dihydrotestosterone; DHTP: Dihydrotestosterone propionate; DPN: Diarylprionate; E2: Estradiol; ER: Estrogen receptor; ERE: Estrogen response element; ESR2: Estrogen receptor 2; GABA: Gamma aminobutyric acid; GC: Glucocorticoid; GDX: Gonadectomy; GR: Glucocorticoid receptor; HPA: Hypothalamic-pituitary-adrenal; iTFM: Induced testicular feminization mutation; MeA: Medial amygdala; MPOA: Medial preoptic area; MR: Mineralocorticoid receptor; POMC: Proopiomelanocortin; PPT: Propylpyrazoltriol; PVN: Paraventricular nucleus; RL-HSD: 11-cis-retinol dehydrogenase; T: Testosterone; Tfm: Testicular feminized mouse; \\ TPH: Tryptophan hydroxylase; V1A: Vasopressin receptor 1A; V2A: Vasopressin receptor $2 \mathrm{~A}$}

\section{Acknowledgements}

The authors' research programs are supported by NIH R15 MH118692 (DGZ) and NIH R01 DK105826 (RJH).

\section{Authors' contributions}

$\mathrm{DZ}, \mathrm{AH}$, and $\mathrm{RH}$ initiated the writing of the manuscript. $\mathrm{AH}$ and $\mathrm{RDG}$ were involved in literature searches. DZ, AH, RDG, and $\mathrm{RH}$ were involved in editing. DZ and RDG were involved in figure construction. The authors read and approved the final manuscript.

\section{Authors' information}

Dr. Damian Zuloaga is currently an Assistant Professor in the Department of Psychology at Albany University. Dr. Ashley Heck is currently a postdoctoral fellow at the Fred Hutchinson Cancer Research Center. Ms. Rose De Guzman is a graduate student in the Department of Psychology at Albany University. Dr. Robert Handa is a Professor in the Department of Biomedical Sciences at Colorado State University. 


\section{Funding}

$\mathrm{NIH}$ R15 MH118692 (DGZ)

NIH R01 DK105826 (RJH)

\section{Availability of data and materials}

Data scoring is not applicable to this article as no datasets were generated or analyzed during the current study.

\section{Ethics approval and consent to participate}

Not applicable

\section{Consent for publication}

Not applicable

\section{Competing interests}

The authors declare that they have no competing interests.

\section{Author details}

'Department of Psychology, University at Albany, Albany, NY, USA.

${ }^{2}$ Department of Biomedical Sciences, Colorado State University, Fort Collins, CO, USA.

Received: 27 January 2020 Accepted: 9 July 2020

Published online: 29 July 2020

\section{References}

1. Dumitriu D, Rapp PR, McEwen BS, Morrison JH. Estrogen and the aging brain: an elixir for the weary cortical network. Ann N Y Acad Sci. 2010;1204: 104-12.

2. Fernández-Guasti A, Fiedler JL, Herrera L, Handa RJ. Sex, stress, and mood disorders: at the intersection of adrenal and gonadal hormones. Horm Metab Res. 2012;44:607-18

3. Handa RJ, Weiser MJ. Gonadal steroid hormones and the hypothalamopituitary-adrenal axis. Front Neuroendocrinol. 2014;35:197-220.

4. Shanmugan S, Epperson CN. Estrogen and the prefrontal cortex: towards a new understanding of estrogen's effects on executive functions in the menopause transition. Hum Brain Mapp. 2014:35:847-65.

5. Nemeroff CB, Widerlöv E, Bissette G, Walléus H, Karlsson I, Eklund K, Kilts CD, Loosen PT, Vale W. Elevated concentrations of CSF corticotropin-releasing factor-like immunoreactivity in depressed patients. Science. 1984;226: 1342-4.

6. Oakley RH, Cidlowski JA. Glucocorticoid signaling in the heart: a cardiomyocyte perspective. J Steroid Biochem Mol Biol. 2015;153:27-34.

7. Wang M. The role of glucocorticoid action in the pathophysiology of the metabolic syndrome. Nutr Metab. 2005;2, 3(1)

8. Xu Y, Nedungadi TP, Zhu L, Sobhani N, Irani BG, Davis KE, et al. Distinct hypothalamic neurons mediate estrogenic effects on energy homeostasis and reproduction. Cell Metab. Cell Press. 2011;14:453-65.

9. Goldstein JM, Holsen L, Huang G, Hammond BD, James-Todd T, Cherkerzian $S$, et al. Prenatal stress-immune programming of sex differences in comorbidity of depression and obesity/metabolic syndrome. Dialogues Clin Neurosci Les Laboratoires Servier. 2016;18:425-36.

10. Heck AL, Handa RJ. Sex differences in the hypothalamic-pituitary-adrenal axis' response to stress: an important role for gonadal hormones. Neuropsychopharmacology. Nature Publishing Group. 2019;1:45-58.

11. Herman JP, Flak J, Jankord R. Chronic stress plasticity in the hypothalamic paraventricular nucleus. Prog Brain Res. 2008;170:353-64.

12. Papadimitriou A, Priftis KN. Regulation of the hypothalamic-pituitary-adrenal axis. Neuroimmunomodulation. 2009:16:265-71.

13. Jauregui-Huerta F, Ruvalcaba-Delgadillo Y, Gonzalez-Perez O, GonzalezCastaneda R, Garcia-Estrada J, Luquin S. Responses of glial cells to stress and glucocorticoids. Curr Immunol Rev. 2010;6:195-204.

14. McEwen BS. Protective and damaging effects of stress mediators: the good and bad sides of the response to stress. Metabolism. 2002:51:2-4.

15. Babb JA, Masini CV, Day HEW, Campeau S. Stressor-specific effects of sex on HPA axis hormones and activation of stress-related neurocircuitry. Stress. 2013;16:664-77.

16. Handa RJ, Nunley KM, Lorens SA, Louie JP, McGivern RF, Bollnow MR. Androgen regulation of adrenocorticotropin and corticosterone secretion in the male rat following novelty and foot shock stressors. Physiol Behav. 1994 55:117-24.
17. Iwasaki-Sekino A, Mano-Otagiri A, Ohata H, Yamauchi N, Shibasaki T. Gender differences in corticotropin and corticosterone secretion and corticotropinreleasing factor mRNA expression in the paraventricular nucleus of the hypothalamus and the central nucleus of the amygdala in response to footshock stress or psychological stress in rats. Psychoneuroendocrinology. 2009;34:226-37.

18. Viau V, Bingham B, Davis J, Lee P, Wong M. Gender and puberty interact on the stress-induced activation of parvocellular neurosecretory neurons and corticotropin-releasing hormone messenger ribonucleic acid expression in the rat. Endocrinology. 2005;146:137-46.

19. Seale JV, Wood SA, Atkinson HC, Bate E, Lightman SL, Ingram CD, et al . Gonadectomy reverses the sexually diergic patterns of circadian and stressinduced hypothalamic-pituitary-adrenal axis activity in male and female rats. J Neuroendocrinol. 2004;16:516-24

20. Larkin JW, Binks SL, Li Y, Selvage D. The role of oestradiol in sexually dimorphic hypothalamic-pituitary-adrena axis responses to intracerebroventricular ethanol administration in the rat. J Neuroendocrinol. 2010;22:24-32.

21. Figueiredo HF, Dolgas CM, Herman JP. Stress activation of cortex and hippocampus is modulated by sex and stage of estrus. Endocrinology. 2002; 143:2534-40.

22. Turner BB, Debra A. W. Sexual dimorphism of glucocorticoid binding in rat brain. Brain Res. 1985;343:16-23.

23. Turner BB. Sex difference in glucocorticoid binding in rat pituitary is estrogen dependent. Life Sci. 1990;46:1399-406.

24. Karandrea D, Kittas C, Kitraki E. Contribution of sex and cellular context in the regulation of brain corticosteroid receptors following restraint stress. Neuroendocrinology. 2000;71:343-53.

25. Solomon MB, Furay AR, Jones K, Packard AEB, Packard BA, Wulsin AC, et al. Deletion of forebrain glucocorticoid receptors impairs neuroendocrine stress responses and induces depression-like behavior in males but not females. Neuroscience. 2012;203:135-43.

26. Solomon MB, Loftspring M, de Kloet AD, Ghosal S, Jankord R, Flak JN, et al. Neuroendocrine function after hypothalamic depletion of glucocorticoid receptors in male and female mice. Endocrinology. 2015;156:2843-53.

27. Heck AL, Thompson MK, Uht RM, Handa RJ. Sex-dependent mechanisms of glucocorticoid regulation of the mouse hypothalamic corticotropinreleasing hormone gene. Endocrinology. 2019;161:bqz012.

28. De Kloet ER, Joëls $M$, Holsboer F. Stress and the brain: from adaptation to disease. Nat Rev Neurosci. 2005;1:463-75.

29. Panagiotakopoulos L, Neigh GN. Development of the HPA axis: where and when do sex differences manifest? Front Neuroendocrinol. 2014:35:285-302

30. Henley DE, Lightman SL. New insights into corticosteroid-binding globulin and glucocorticoid delivery. Neuroscience. 2011;180:1-8.

31. Gala RR, Westphal U. Corticosteroid-binding globulin in the rat: studies on the sex difference. Endocrinology. 1965:77:841-51.

32. McCormick CM, Linkroum W, Sallinen BJ, Miller NW. Peripheral and central sex steroids have differential effects on the HPA axis of male and female rats. Stress. 2002;5:235-47.

33. Tannenbaum B, Rowe W, Sharma S, Diorio J, Steverman A, Walker M, et al. Dynamic variations in plasma corticosteroid-binding globulin and basal HPA activity following acute stress in adult rats. J Neuroendocrinol. 1997:9:163-8.

34. Griffin AC, Whitacre CC. Sex and strain differences in the circadian rhythm fluctuation of endocrine and immune function in the rat: implications for rodent models of autoimmune disease. J Neuroimmunol. 1991;35:53-64.

35. Windle RJ, Wood SA, Lightman SL, Ingram CD. The pulsatile characteristics of hypothalamo-pituitary-adrenal activity in female Lewis and Fischer 344 rats and its relationship to differential stress responses. Endocrinology. 1998;139:4044-52.

36. Taylor AN, Tio DL, Romeo HE. The febrile response to intraperitoneal lipopolysaccharide: strain and gender differences in rats. J Neuroimmunol. 2005;158:86-93.

37. Chisari A, Carino M, Perone M, Gaillard RC, Spinedi E. Sex and strain variability in the rat hypothalamo-pituitary-adrenal (HPA) axis function. $J$ Endocrinol Invest. 1995;18:25-33.

38. Brown KJ, Grunberg NE. Effects of housing on male and female rats: crowding stresses males but calms females. Physiol Behav. 1995;58:1085-9.

39. Westenbroek C, Den Boer JA, Ter Horst GJ. Gender-specific effects of social housing on chronic stress-induced limbic FOS expression. Neuroscience. 2003:121:189-99.

40. Bangasser DA, Valentino RJ. Sex differences in stress-related psychiatric disorders: neurobiological perspectives. Front Neuroendocrinol. 2014:35: 303-319. 
41. Gomez F, Manalo S, Dallman MF. Androgen-sensitive changes in regulation of restraint-induced adrenocorticotropin secretion between early and late puberty in male rats. Endocrinology. 2004;145:59-70.

42. Kirschbaum C, Kudielka BM, Gaab J, Schommer NC, Hellhammer DH. Impact of gender, menstrual cycle phase, and oral contraceptives on the activity of the hypothalamus-pituitary-adrenal axis. Psychosom Med. 1999;61:154-62.

43. Kudielka BM, Kirschbaum C. Sex differences in HPA axis responses to stress: a review. Biol Psychol. Elsevier. 2005:113-32.

44. Seeman TE, Singer B, Wilkinson CW, McEwen B. Gender differences in agerelated changes in HPA axis reactivity. Psychoneuroendocrinology. 2001;26: 225-40.

45. Uhart M, Chong RY, Oswald L, Lin P-I. Wand GS. Gender differences in hypothalamic-pituitary-adrenal (HPA) axis reactivity. Psychoneuroendocrinology. 2006;31:642-52

46. Kessler RC, McGonagle KA, Nelson CB, Hughes M, Swartz M, Blazer DG. Sex and depression in the national comorbidity survey. II: Cohort effects. J Affect Disord. 1994;30:15-26.

47. Gater R, Tansella M, Korten A, Tiemens BG, Mavreas VG, Olatawura MO. Sex differences in the prevalence and detection of depressive and anxiety disorders in general health care settings:report from the world health organization collaborative study on psychological problems in general health care. Arch Gen Psychiatry. 1998:55:405-13.

48. Weissman MM, Bland RC, Canino GJ, Faravelli C, Greenwald S, Hwu HG, et al. Cross-national epidemiology of major depression and bipolar disorder. J Am Med Assoc. 1996;276:293-9.

49. Nolen-Hoeksema S, Larson J, Grayson C. Explaining the gender difference in depressive symptoms. J Pers Soc Psychol. 1999;77:1061-72.

50. Hankin BL. Development of sex differences in depressive and co-occurring anxious symptoms during adolescence: descriptive trajectories and potential explanations in a multiwave prospective study. J Clin Child Adolesc Psychol. 2009;38:460-72.

51. Goldstein JM, Handa RJ, Tobet SA. Disruption of fetal hormonal programming (prenatal stress) implicates shared risk for sex differences in depression and cardiovascular disease. Front Neuroendocrinol. 2014;35:140-58.

52. Imhof JT, Coelho ZM, Schmitt ML, Morato GS, Carobrez AP. Influence of gender and age on performance of rats in the elevated plus maze apparatus. Behav Brain Res. 1993;56:177-80.

53. Zimmerberg B, Farley MJ. Sex differences in anxiety behavior in rats: role of gonadal hormones. Physiol Behav. 1993;54:1119-24.

54. Steenbergen HL, Heinsbroek RPW, Van Hest A, Van de Poll NE. Sex-dependent effects of inescapable shock administration on shuttlebox-escape performance and elevated plus-maze behavior. Physiol Behav. 1990:48:571-6.

55. Barros HMT, Ferigolo M. Ethopharmacology of imipramine in the forcedswimming test: gender differences. Neurosci Biobehav Rev. 1998:23:279-86.

56. Kokras N, Dalla C. Sex differences in animal models of psychiatric disorders. Br J Pharmacol. 2014;171:4595-619.

57. Lu Y, Zhang J, Zhang L, Dang S, Su Q, Zhang H, et al. Hippocampal acetylation may improve prenatal-stress-induced depression-like behavior of male offspring rats through regulating AMPARs expression. Neurochem Res. 2017;42:3456-64

58. Paré WP, Redei E. Sex differences and stress response of WKY rats. Physiol Behav. 1993;54:1179-85.

59. Võikar V, Kõks S, Vasar E, Rauvala H. Strain and gender differences in the behavior of mouse lines commonly used in transgenic studies. Physiol Behav. 2001:72:271-81

60. Yau S-Y, Lee TH-Y, Formolo DA, Lee W-L, Li LC-K, Siu PM, et al. Effects of maternal voluntary wheel running during pregnancy on adult hippocampal neurogenesis, temporal order memory, and depression-like behavior in adult female and male offspring. Front Neurosci. 2019;13:470.

61. Burke NN, Coppinger J, Deaver DR, Roche M, Finn DP, Kelly J. Sex differences and similarities in depressive- and anxiety-like behaviour in the Wistar-Kyoto rat. Physiol Behav. Elsevier Inc. 2016;167:28-34.

62. Bielajew C, Konkle ATM, Kentner AC, Baker SL, Stewart A, Hutchins AA, et al. Strain and gender specific effects in the forced swim test: effects of previous stress exposure. Stress. 2003;6:269-80

63. Colom-Lapetina J, Begley SL, Johnson ME, Bean KJ, Kuwamoto WN, Shansky RM. Strain-dependent sex differences in a long-term forced swim paradigm. Behav Neurosci. 2017;131:428-36.

64. Hong S, Flashner B, Chiu M, ver Hoeve E, Luz S, Bhatnagar S. Social isolation in adolescence alters behaviors in the forced swim and sucrose preference tests in female but not in male rats. Physiol Behav. 2012;105:269-75.
65. Palanza P, Gioiosa L, Parmigiani S. Social stress in mice: gender differences and effects of estrous cycle and social dominance. Physiol Behav. 2001;73:411-20.

66. Fernandes C, González MI, Wilson CA, File SE. Factor analysis shows that female rat behaviour is characterized primarily by activity, male rats are driven by sex and anxiety. Pharmacol Biochem Behav. 1999;64:731-6.

67. File SE. Factors controlling measures of anxiety and responses to novelty in the mouse. Behav Brain Res. 2001;125:151-7.

68. Frye CA, Petralia SM, Rhodes ME. Estrous cycle and sex differences in performance on anxiety tasks coincide with increases in hippocampal progesterone and 3a,5a-THP. Pharmacol Biochem Behav. 2000;67:587-96.

69. Hodes GE, Pfau ML, Purushothaman I, Francisca Ahn H, Golden SA, Christoffel DJ, et al. Sex differences in nucleus accumbens transcriptome profiles associated with susceptibility versus resilience to subchronic variable stress. J Neurosci Soc Neurosci. 2015;35:16362-76.

70. Williams ES, Manning CE, Eagle AL, Swift-Gallant A, Duque-Wilckens N, Chinnusamy $\mathrm{S}$, et al. Androgen-dependent excitability of mouse ventral hippocampal afferents to nucleus accumbens underlies sex-specific susceptibility to stress. Biol Psychiatry. 2019;87(6):492.

71. Beck KD, Luine VN. Sex differences in behavioral and neurochemical profiles after chronic stress: role of housing conditions. Physiol Behav. 2002;75:661-73.

72. Bowman RE, Maclusky NJ, Diaz SE, Zrull MC, Luine VN. Aged rats: sex differences and responses to chronic stress. Brain Res. 2006;1126:156-66.

73. Rosinger Z, De Guzman RM, Jacobskind JS, Saglimbeni B, Malone M, Fico D, et al. Sex-dependent effects of chronic variable stress on discrete corticotropin-releasing factor receptor 1 cell populations. Physiol Behav. 2020;219:1.

74. Springer C, Misurell JR, Hiller A. Game-based cognitive-behavioral therapy (GB-CBT) group program for children who have experienced sexual abuse: a three-month follow-up investigation. J Child Sex Abus. 2012;21:646-64.

75. Curley JP, Jensen CL, Mashoodh R, Champagne FA. Social influences on neurobiology and behavior: epigenetic effects during development. Psychoneuroendocrinology. 2011;36:352-71.

76. Altemus M, Sarvaiya N, Neill EC. Sex differences in anxiety and depression clinical perspectives. Front. Neuroendocrinol. 2014;35:320-30.

77. Bale TL, Epperson CN. Sex differences and stress across the lifespan. Nat. Neurosci. 2015;18:1413-20.

78. Nolen-Hoeksema S. Sex differences in unipolar depression: evidence and theory. Psychol Bull. 1987;101:259-82.

79. Soares CN, Zitek B. Reproductive hormone sensitivity and risk for depression across the female life cycle: a continuum of vulnerability? J Psychiatry Neurosci. 2008;33:331-43.

80. Noble RE. Depression in women. Metabolism. 2005;54:49-52.

81. Laughlin-Tommaso SK, Satish A, Khan Z, Smith CY, Rocca WA, Stewart EA. Long-term risk of de novo mental health conditions after hysterectomy with ovarian conservation: a cohort study. Menopause 2020:27:33-42.

82. Pletzer BA, Kerschbaum HH. 50 years of hormonal contraception - time to find out, what it does to our brain. Front Neurosci. 2014:8:256.

83. Basson R. Review: Testosterone therapy for reduced libido in women. Ther Adv Endocrinol Metab. 2010:1:155-64.

84. O'Regan D, Kenyon CJ, Seckl JR, Holmes MC. Glucocorticoid exposure in late gestation in the rat permanently programs gender-specific differences in adult cardiovascular and metabolic physiology. Am J Physiol Endocrinol Metab. 2004;287:E863-70.

85. O'Regan D, Kenyon CJ, Seckl JR, Holmes MC. Prenatal dexamethasone "programmes" hypotension, but stress-induced hypertension in adult offspring. J Endocrinol. 2008;196:343-52.

86. Carbone DL, Zuloaga DG, Hiroi R, Foradori CD, Legare ME, Handa RJ. Prenatal dexamethasone exposure potentiates diet-induced hepatosteatosis and decreases plasma IGF-I in a sex-specific fashion. Endocrinology. 2012; $153: 295$.

87. Carbone DL, Zuloaga DG, Lacagnina AF, Handa RJ. Prepro-thyrotropin releasing hormone expressing neurons in the juxtaparaventricular region of the lateral hypothalamus are activated by leptin and altered by prenatal glucocorticoid exposure. Brain Res. 2012;1477:19.

88. Zuloaga DG, Carbone DL, Quihuis A, Hiroi R, Chong DL, Handa RJ. Perinatal dexamethasone-induced alterations in apoptosis within the hippocampus and paraventricular nucleus of the hypothalamus are influenced by age and sex. J Neurosci Res. 2012;90:1403.

89. Zuloaga DG, Carbone DL, Hiroi R, Chong DL, Handa RJ. Dexamethasone induces apoptosis in the developing rat amygdala in an age-, region-, and sex-specific manner. Neuroscience. 2011;199:535. 
90. Handa RJ, Burgess LH, Kerr JE, O'keefe JA. Gonadal steroid hormone receptors and sex differences in the hypothalamo-pituitary-adrenal axis. Horm Behav. 1994;28:464-76.

91. Viau V, Meaney MJ. Testosterone-dependent variations in plasma and intrapituitary corticosteroid binding globulin and stress hypothalamicpituitary-adrenal activity in the male rat. J Endocrinol. 2004;181:223-31.

92. Handa RJ, Kudwa AE, Donner NC, McGivern RF, Brown R. Central 5-alpha reduction of testosterone is required for testosterone's inhibition of the hypothalamo-pituitary-adrenal axis response to restraint stress in adult male rats. Brain Res. 2013;1529:74-82.

93. Lund TD, Hinds LR, Handa RJ. The androgen 5alpha-dihydrotestosterone and its metabolite 5alpha-androstan-3beta, 17beta-diol inhibit the hypothalamo-pituitary-adrenal response to stress by acting through estrogen receptor beta-expressing neurons in the hypothalamus. J Neurosci. 2006;26:1448-56.

94. Handa RJ, Weiser MJ, Zuloaga DG. A role for the androgen metabolite, 5alpha-androstane-3beta,17beta-diol, in modulating oestrogen receptor beta-mediated regulation of hormonal stress reactivity. J Neuroendocrinol. 2009:21:351-8.

95. Amore M, Innamorati M, Costi S, Sher L, Girardi P, Pompili M. Partial androgen deficiency, depression, and testosterone supplementation in aging men. Int J Endocrinol. 2012;2012:280724

96. Aydogan U, Aydogdu A, Akbulut H, Sonmez A, Yuksel S, Basaran Y, et al. Increased frequency of anxiety, depression, quality of life and sexual life in young hypogonadotropic hypogonadal males and impacts of testosterone replacement therapy on these conditions. Endocr J. 2012;59:1099-105.

97. Burris AS, Banks SM, Carter CS, Davidson JM, Sherins RJ. A long-term, prospective study of the physiologic and behavioral effects of hormone replacement in untreated hypogonadal men. J Androl. 1992;13:297-304.

98. Wang C, Alexander G, Berman N, Salehian B, Davidson T, McDonald V, et al. Testosterone replacement therapy improves mood in hypogonadal men--a clinical research center study. J Clin Endocrinol Metab. 1996;81:3578-83.

99. Snyder PJ, Bhasin S, Cunningham GR, Matsumoto AM, Stephens-Shields AJ, Cauley JA, et al. Effects of testosterone treatment in older men. $\mathrm{N}$ Engl J Med. 2016;374:611-24.

100. Rubinow DR, Roca CA, Schmidt PJ, Danaceau MA, Putnam K, Cizza G, et al. Testosterone suppression of $\mathrm{CRH}$-stimulated cortisol in men. Neuropsychopharmacology. 2005;30:1906-12.

101. Russell AL, Tasker JG, Lucion AB, Fiedler J, Munhoz CD, Wu T-YJ, et al. Factors promoting vulnerability to dysregulated stress reactivity and stressrelated disease. J Neuroendocrinol. 2018;30:e12641.

102. Domonkos E, Hodosy J, Ostatníková D, Celec P. On the role of testosterone in anxiety-like behavior across life in experimental rodents. Front Endocrinol (Lausanne). 2018;9:441.

103. Adler A, Vescovo P, Robinson JK, Kritzer MF. Gonadectomy in adult life increases tyrosine hydroxylase immunoreactivity in the prefrontal cortex and decreases open field activity in male rats. Neuroscience. 1999;89:939-54.

104. Frye CA, Seliga AM. Testosterone increases analgesia, anxiolysis, and cognitive performance of male rats. Cogn Affect Behav Neurosci. Psychonomic Society Inc. 2001;1:371-81.

105. Slob AK, Bogers H, Van Stolk MA. Effects of gonadectomy and exogenous gonadal steroids on sex differences in open field behaviour of adult rats. Behav Brain Res. 1981;2:347-62.

106. Zuloaga DG, Morris JA, Jordan CL, Breedlove SM. Mice with the testicular feminization mutation demonstrate a role for androgen receptors in the regulation of anxiety-related behaviors and the hypothalamic-pituitaryadrenal axis. Horm Behav. 2008;54.

107. Liang Y, Li J, Jin T, Gu T, Zhu Q, Hu Y, et al. Bisphenol-A inhibits improvement of testosterone in anxiety- and depression-like behaviors in gonadectomied male mice. Horm Behav. 2018;102:129-38.

108. Chen CV, Brummet JL, Lonstein JS, Jordan CL, Breedlove SM. New knockout model confirms a role for androgen receptors in regulating anxiety-like behaviors and HPA response in mice. Horm Behav. 2014;65:211-8.

109. Goel N, Bale TL. Organizational and activational effects of testosterone on masculinization of female physiological and behavioral stress responses. Endocrinology. 2008;149:6399-405.

110. Edinger KL, Frye CA. Sexual experience of male rats influences anxiety-like behavior and androgen levels. Physiol Behav. 2007;92:443-53.

111. Aikey $J$, Nyby JG, Anmuth DM, James PJ. Testosterone rapidly reduces anxiety in male house mice (Mus musculus). Horm Behav. 2002;42:448-60
112. Frye CA, Edinger K, Sumida K. Androgen administration to aged male mice increases anti-anxiety behavior and enhances cognitive performance. Neuropsychopharmacology. 2008;33:1049-61.

113. Osborne DM, Edinger K, Frye CA, et al. Age (Omaha). 2009:191-8.

114. Fernández-Guasti A, Martínez-Mota L. Anxiolytic-like actions of testosterone in the burying behavior test: role of androgen and GABA-benzodiazepine receptors. Psychoneuroendocrinology. 2005;30:762-70.

115. McCarthy MM, Nugent BM. At the frontier of epigenetics of brain sex differences. Front. Behav. Neurosci. Frontiers Media S.A.; 2015.

116. Morris JA, Jordan CL, Breedlove SM. Sexual differentiation of the vertebrate nervous system. Nat. Neurosci. 2004. p. 1034-9.

117. Zuloaga DG, Jordan CL, Breedlove SM. Sexual differentiation of the brain. Neurosci: Encycl; 2009.

118. Zuloaga DG, Jordan CL, Breedlove SM. The organizational role of testicular hormones and the androgen receptor in anxiety-related behaviors and sensorimotor gating in rats. Endocrinology. 2011;152(4):1572-81.

119. McCormick CM, Furey BF, Child M, Sawyer MJ, Donohue SM. Neonatal sex hormones have "organizational" effects on the hypothalamic- pituitaryadrenal axis of male rats. Dev Brain Res. 1998;105:295-307.

120. Seale JV, Wood SA, Atkinson HC, Harbuz MS, Lightman SL. Postnatal masculinization alters the HPA axis phenotype in the adult female rat. J Physiol. 2005;563:265-74.

121. Bingham $B$, Wang NXR, Innala L, Viau V. Postnatal aromatase blockade increases $c$-fos mRNA responses to acute restraint stress in adult male rats. Endocrinology. 2012;153:1603-8.

122. Hu M, Richard JE, Maliqueo M, Kokosar M, Fornes R, Benrick A, et al. Maternal testosterone exposure increases anxiety-like behavior and impacts the limbic system in the offspring. Proc Natl Acad Sci U S A. 2015;112: 14348-53.

123. Lucion $A B$, Charchat $H$, Pereira GA, Rasia-Filho AA. Influence of early postnatal gonadal hormones on anxiety in adult male rats. Physiol Behav. 1996:60:1419-23.

124. Romeo RD. Puberty: a period of both organizational and activational effects of steroid hormones on neurobehavioural development. J Neuroendocrinol. 2003;15:1185-92.

125. Romeo RD, Lee SJ, Chhua N, McPherson CR, BS ME. Testosterone cannot activate an adult-like stress response in prepubertal male rats. Neuroendocrinology. 2004;79:125-32.

126. Romeo RD, Lee SJ, McEwen BS. Differential stress reactivity in intact and ovariectomized prepubertal and adult female rats. Neuroendocrinology. 2004;80:387-93.

127. Romeo RD. The metamorphosis of adolescent hormonal stress reactivity: a focus on animal models. Front. Neuroendocrinol. Academic Press Inc. 2018: 43-51.

128. Evuarherhe O, Leggett JD, Waite EJ, Kershaw YM, Atkinson HC, Lightman SL. Organizational role for pubertal androgens on adult hypothalamic-pituitaryadrenal sensitivity to testosterone in the male rat. J Physiol. 2009;587: 2977-85.

129. Evuarherhe O, Leggett J, Waite E, Kershaw Y, Lightman S. Reversal of the hypothalamo-pituitary-adrenal response to oestrogens around puberty. J Endocrinol. 2009;202:279-85.

130. Brand T, Slob AK. Peripubertal castration of male rats, adult open field ambulation and partner preference behavior. Behav Brain Res. 1988;30: $111-7$.

131. Brown GR, Kulbarsh KD, Spencer KA, Duval C. Peri-pubertal exposure to testicular hormones organizes response to novel environments and social behaviour in adult male rats. Horm Behav. 2015;73:135-41.

132. Boivin JR, Piekarski DJ, Wahlberg JK, Wilbrecht L. Age, sex, and gonadal hormones differently influence anxiety- and depression-related behavior during puberty in mice. Psychoneuroendocrinology. 2017;85:78-87.

133. Delevich K, Hall CD, Piekarski D, Zhang Y, Wilbrecht L. Prepubertal gonadectomy reveals sex differences in approach-avoidance behavior in adult mice. Horm Behav. 2019;118:104641

134. McCormick CM, Mahoney E. Persistent effects of prenatal, neonatal, or adult treatment with flutamide on the hypothalamic-pituitary-adrenal stress response of adult male rats. Horm Behav. 1999;35:90-101.

135. Belelli D, Lambert JJ. Neurosteroids: endogenous regulators of the GABAA receptor. Nat. Rev. Neurosci. 2005:565-75.

136. Lambert JJ, Harney SC, Belelli D, Peters JA. Neurosteroid modulation of recombinant and synaptic GABAA receptors. Int Rev Neurobiol. 2001;46: 177-205. 
137. Zuloaga DG, Puts DA, Jordan CL, Breedlove SM. The role of androgen receptors in the masculinization of brain and behavior: what we've learned from the testicular feminization mutation. Horm Behav. 2008;53:613-26.

138. Zuloaga DG, Poort JE, Jordan CL, Breedlove SM. Male rats with the testicular feminization mutation of the androgen receptor display elevated anxietyrelated behavior and corticosterone response to mild stress. Horm Behav. 2011;60:380-8

139. Roselli CE, Salisbury RL, Resko JA. Genetic evidence for androgen-dependent and independent control of aromatase activity in the rat brain. Endocrinology. 1987;121:2205-10.

140. Hamson DK, Jones BA, Csupity AS, Ali FM, Watson NV. Androgen insensitive male rats display increased anxiety-like behavior on the elevated plus maze. Behav Brain Res. 2014;259:158-63.

141. Hung $Y-Y$, Huang $Y$-L, Chang $C$, Kang H-Y. Deficiency in androgen receptor aggravates the depressive-like behaviors in chronic mild stress model of depression. Cells. 2019;8:1021

142. Cherrier MM, Aubin S, Higano CS. Cognitive and mood changes in men undergoing intermittent combined androgen blockade for non-metastatic prostate cancer. Psychooncology. 2009;18:237-47.

143. Lee M, Jim HS, Fishman M, Zachariah B, Heysek R, Biagioli M, et al. Depressive symptomatology in men receiving androgen deprivation therapy for prostate cancer: a controlled comparison. Psychooncology. 2015;24:472-7.

144. Fliegner M, Krupp K, Brunner F, Rall K, Brucker SY, Briken P, et al. Sexual life and sexual wellness in individuals with complete androgen insensitivity syndrome (CAIS) and Mayer-Rokitansky-Küster-Hauser Syndrome (MRKHS). J Sex Med. 2014;11:729-42.

145. Wang S-S, Kamphuis W, Huitinga I, Zhou J-N, Swaab DF. Gene expression analysis in the human hypothalamus in depression by laser microdissection and real-time PCR: the presence of multiple receptor imbalances. Mol Psychiatry. 2008;13:786-99, 741

146. Miyamoto J, Matsumoto T, Shiina H, Inoue K, Takada I, Ito S, et al. The pituitary function of androgen receptor constitutes a glucocorticoid production circuit. Mol Cell Biol. 2007;27:4807-14.

147. Mcabee MD, Doncarlos LL. Ontogeny of region-specific sex differences in androgen receptor messenger ribonucleic acid expression in the rat forebrain. Endocrinology. 1998;139:1738-45.

148. Lu SF, McKenna SE, Cologer-Clifford A, Nau EA, Simon NG. Androgen receptor in mouse brain: sex differences and similarities in autoregulation. Endocrinology. 1998;139:1594-601.

149. Williamson M, Viau V. Androgen receptor expressing neurons that project to the paraventricular nucleus of the hypothalamus in the male rat. J Comp Neurol. 2007;503:717-40

150. Bingham B, Myung C, Innala L, Gray M, Anonuevo A, Viau V. Androgen receptors in the posterior bed nucleus of the stria terminalis increase neuropeptide expression and the stress-induced activation of the paraventricular nucleus of the hypothalamus. Neuropsychopharmacology. 2011;36:1433-43.

151. Lebow MA, Chen A. Overshadowed by the amygdala: the bed nucleus of the stria terminalis emerges as key to psychiatric disorders. Mol. Psychiatry. 2016:450-63.

152. Bingaman EW, Baeckman LM, Yracheta JM, Handa RJ, Gray TS. Localization of androgen receptor within peptidergic neurons of the rat forebrain. Brain Res Bull. 1994;35:379-82.

153. Jiang Z, Rajamanickam S, Justice NJ. CRF signaling between neurons in the paraventricular nucleus of the hypothalamus (PVN) coordinates stress responses. Neurobiol. Stress. 2019;11:100192.

154. Jiang Z, Rajamanickam S, Justice NJ. Local corticotropin-releasing factor signaling in the hypothalamic paraventricular nucleus. J Neurosci. 2018;38:1874-90.

155. Rosinger ZJ, Jacobskind JS, De Guzman RM, Justice NJ, Zuloaga DG. A sexually dimorphic distribution of corticotropin-releasing factor receptor 1 in the paraventricular hypothalamus. Neuroscience. 2019;409.

156. Füzesi T, Daviu N, Wamsteeker Cusulin Jl, Bonin RP, Bains JS. Hypothalamic $\mathrm{CRH}$ neurons orchestrate complex behaviours after stress. Nat Commun. 2016;7:11937. [cited 2020 Jan 16]. Available from: http://www.ncbi.nlm.nih. gov/pubmed/27306314.

157. Lund TD, Rovis T, Chung WCJ, Handa RJ. Novel actions of estrogen receptorbeta on anxiety-related behaviors. Endocrinology. 2005;146:797-807.

158. Weiser MJ, Handa RJ. Estrogen impairs glucocorticoid dependent negative feedback on the hypothalamic-pituitary-adrenal axis via estrogen receptor alpha within the hypothalamus. Neuroscience. 2009;159:883-95.
159. Pooley AE, Benjamin RC, Sreedhar S, Eagle AL, Robison AJ, Mazei-Robison MS, et al. Sex differences in the traumatic stress response: the role of adult gonadal hormones. Biol Sex Differ. 2018;9:32.

160. Borrow AP, Handa RJ. Estrogen receptors modulation of anxiety-like behavior. Vitam Horm. 2017:27-52.

161. Jacome LF, Gautreaux C, Inagaki T, Mohan G, Alves S, Lubbers LS, et al. Estradiol and ER $\beta$ agonists enhance recognition memory, and DPN, an ER $\beta$ agonist, alters brain monoamines. Neurobiol Learn Mem. 2010;94: 488-98.

162. Walf AA, Frye CA. ERbeta-selective estrogen receptor modulators produce antianxiety behavior when administered systemically to ovariectomized rats Neuropsychopharmacology. 2005;30:1598-609.

163. Byrnes EM, Casey K, Carini LM, Bridges RS. Reproductive experience alters neural and behavioural responses to acute oestrogen receptor a activation. J Neuroendocrinol. 2013;25:1280-9.

164. Byrnes EM, Casey K, Bridges RS. Reproductive experience modifies the effects of estrogen receptor alpha activity on anxiety-like behavior and corticotropin releasing hormone mRNA expression. Horm Behav. 2012;61: 44-9.

165. Krezel W, Dupont S, Krust A, Chambon P, Chapman PF. Increased anxiety and synaptic plasticity in estrogen receptor beta-deficient mice. Proc Natl Acad Sci U S A. 2001;98:12278-82.

166. Imwalle DB, Scordalakes EM, Rissman EF. Estrogen receptor a influences socially motivated behaviors. Horm Behav. Academic Press Inc. 2002;42:48491.

167. Comings DE, Muhleman D, Johnson P, MacMurray JP. Potential role of the estrogen receptor gene (ESR1) in anxiety. Mol Psychiatry. 1999;4:374-7.

168. Ryan J, Scali J, Carrière I, Peres K, Rouaud O, Scarabin P-Y, et al. Oestrogen receptor polymorphisms and late-life depression. Br J Psychiatry. 2011;199: 126-31.

169. Ryan J, Ancelin M-L. Polymorphisms of estrogen receptors and risk of depression: therapeutic implications. Drugs. 2012;72:1725-38.

170. Laflamme N, Nappi RE, Drolet G, Labrie C, Rivest S. Expression and neuropeptidergic characterization of estrogen receptors (ERa and ERß) throughout the rat brain: anatomical evidence of distinct roles of each subtype. J Neurobiol. 1998;36:357-78.

171. Oyola MG, Thompson MK, Handa AZ, Handa RJ. Distribution and chemical composition of estrogen receptor $\beta$ neurons in the paraventricular nucleus of the female and male mouse hypothalamus. J Comp Neurol. 2017;525: 3666-82.

172. Mitra SW, Hoskin E, Yudkovitz J, Pear L, Wilkinson HA, Hayashi S, et al. Immunolocalization of estrogen receptor beta in the mouse brain: comparison with estrogen receptor alpha. Endocrinology. 2003;144:2055-67.

173. Shughrue PJ, Lane MV, Merchenthaler I. Comparative distribution of estrogen receptor- $\alpha$ and $-\beta$ mRNA in the rat central nervous system. $J$ Comp Neurol. 1997;388:507-25.

174. Lorsch ZS, Loh Y-HE, Purushothaman I, Walker DM, Parise EM, Salery M, et al. Estrogen receptor a drives pro-resilient transcription in mouse models of depression. Nat Commun. 2018:9:1116.

175. Spiteri T, Musatov S, Ogawa S, Ribeiro A, Pfaff DW, Agmo A. The role of the estrogen receptor alpha in the medial amygdala and ventromedial nucleus of the hypothalamus in social recognition, anxiety and aggression. Behav Brain Res. 2010;210:211-20.

176. Spiteri T, Ogawa S, Musatov S, Pfaff DW, Agmo A. The role of the estrogen receptor $a$ in the medial preoptic area in sexual incentive motivation, proceptivity and receptivity, anxiety, and wheel running in female rats. Behav Brain Res. 2012;230:11-20.

177. Kuiper GGJM, Carlsson B, Grandien K, Enmark E, Häggblad J, Nilsson S, et al. Comparison of the ligand binding specificity and transcript tissue distribution of estrogen receptors and $\alpha$ and $\beta$. Endocrinology. 1997;138:863-70.

178. Guerini V, Sau D, Scaccianoce E, Rusmini P, Ciana P, Maggi A, et al. The androgen derivative $5 a$-androstane-3 $\beta, 17 \beta$-diol inhibits prostate cancer cell migration through activation of the estrogen receptor $\beta$ subtype. Cancer Res. 2005:65:5445-53.

179. Oyola MG, Portillo W, Reyna A, Foradori CD, Kudwa A, Hinds L, et al. Anxiolytic effects and neuroanatomical targets of estrogen receptor- $\beta$ (ERB) activation by a selective ER $\beta$ agonist in female mice. Endocrinology. 2012; 153:837-46.

180. Lund TD, Munson DJ, Haldy ME, Handa RJ. Dihydrotestosterone may inhibit hypothalamo-pituitary-adrenal activity by acting through estrogen receptor in the male mouse. Neurosci Lett. 2004;365:43-7. 
181. Handa RJ, Pak TR, Kudwa AE, Lund TD, Hinds L. An alternate pathway for androgen regulation of brain function: activation of estrogen receptor beta by the metabolite of dihydrotestosterone, 5alpha-androstane-3beta,17betadiol. Horm Behav. 2008:53:741-52.

182. Frye CA, Koonce CJ, Edinger $\mathrm{KL}$, Osborne DM, Walf AA. Androgens with activity at estrogen receptor beta have anxiolytic and cognitive-enhancing effects in male rats and mice. Horm Behav. 2008;54:726-34.

183. Georgiou P, Zanos P, Jenne CE, Gould TD. Sex-specific involvement of estrogen receptors in behavioral responses to stress and psychomotor activation. Front psychiatry. 2019;10:81.

184. Keyes K, Agnew-Blais J, Roberts AL, Hamilton A, De Vivo I, Ranu H, et al. The role of allelic variation in estrogen receptor genes and major depression in the Nurses Health Study. Soc Psychiatry Psychiatr Epidemiol. 2015;50:1893904.

185. Suzuki S, Handa RJ. Estrogen receptor- $\beta$, but not estrogen receptor-a, is expressed in prolactin neurons of the female rat paraventricular and supraoptic nuclei: comparison with other neuropeptides. J Comp Neurol. 2005;484:28-42.

186. Zuloaga DG, Zuloaga KL, Hinds LR, Carbone DL, Handa RJ. Estrogen receptor $\beta$ expression in the mouse forebrain: age and sex differences. $J$ Comp Neurol. 2014;522.

187. Foidart A, Harada N, Balthazart J. Aromatase-immunoreactive cells are present in mouse brain areas that are known to express high levels of aromatase activity. Cell Tissue Res. 1995;280:561-74.

188. Hrabovszky E, Kalló I, Steinhauser A, Merchenthaler I, Coen CW, Petersen SL, et al. Estrogen receptor-beta in oxytocin and vasopressin neurons of the rat and human hypothalamus: immunocytochemical and in situ hybridization studies. J Comp Neurol. 2004;473:315-33.

189. Kanaya M, Higo S, Ozawa H. Neurochemical characterization of neurons expressing estrogen receptor $\beta$ in the hypothalamic nuclei of rats using in situ hybridization and immunofluorescence. Int J Mol Sci. 2019;21:115.

190. Nishitani N, Nagayasu K, Asaoka N, Yamashiro M, Andoh C, Nagai Y, et al. Manipulation of dorsal raphe serotonergic neurons modulates active coping to inescapable stress and anxiety-related behaviors in mice and rats. Neuropsychopharmacology. 2019;44:721-32.

191. Donner N, Handa RJ. Estrogen receptor beta regulates the expression of tryptophan-hydroxylase 2 mRNA within serotonergic neurons of the rat dorsal raphe nuclei. Neuroscience. 2009;163:705-18.

192. Gundlah C, Lu NZ, Mirkes SJ, Bethea CL. Estrogen receptor beta (ERß) mRNA and protein in serotonin neurons of macaques. Mol Brain Res. 2001;91:14-22.

193. Suzuki H, Barros RPA, Sugiyama N, Krishnan V, Yaden BC, Kim H-J, et al. Involvement of estrogen receptor $\beta$ in maintenance of serotonergic neurons of the dorsal raphe. Mol Psychiatry. 2013;18:674-80.

194. Long JB, Youngblood WW, Kizer JS. Effects of castration and adrenalectomy on in vitro rates of tryptophan hydroxylation and levels of serotonin in microdissected brain nuclei of adult male rats. Brain Res. 1983;277:289-97.

195. Bethea CL, Coleman K, Phu K, Reddy AP, Phu A. Relationships between androgens, serotonin gene expression and innervation in male macaques. Neuroscience. 2014;274:341-56.

196. Campos GV, de Noronha SR, de Souza AA, Lima PM, Abreu AR, Chianca-Jr D, et al. Estrogen receptor $\beta$ activation within dorsal raphe nucleus reverses anxiety-like behavior induced by food restriction in female rats. Behav Brain Res. Elsevier B.V. 2019;357-358:57-64

197. Mangelsdorf DJ, Thummel C, Beato M, Herrlich P, Schütz G, Umesono K, et al. The nuclear receptor superfamily: the second decade. Cell. 1995;83:835-9.

198. Bennett NC, Gardiner RA, Hooper JD, Johnson DW, Gobe GC. Molecular cell biology of androgen receptor signalling. Int. J. Biochem. Cell Biol. 2010; p. 813-27

199. Paech K, Webb P, Kuiper GGJM, Nilsson S, Gustafsson JÅ, Kushner PJ, et al. Differential ligand activation of estrogen receptors ERa and ER $\beta$ at AP1 sites. Science. 1997;277:1508-10.

200. Foradori CD, Weiser MJ, Handa RJ. Non-genomic actions of androgens. Front. Neuroendocrinol. 2008;29:169-81.

201. Vasudevan N, Pfaff DW. Non-genomic actions of estrogens and their interaction with genomic actions in the brain. Front. Neuroendocrinol. 2008; 29:238-57.

202. Nemeroff CB. The role of GABA in the pathophysiology and treatment of anxiety disorders. Psychopharmacol. Bull. 2003. 37 p. 133-46.

203. Xu H, Qin S, Carrasco GA, Dai Y, Filardo EJ, Prossnitz ER, et al. Extra-nuclear estrogen receptor GPR30 regulates serotonin function in rat hypothalamus. Neuroscience. 2009;158:1599-607.
204. McAllister CE, Creech RD, Kimball PA, Muma NA, Li Q. GPR30 is necessary for estradiol-induced desensitization of 5-HT 1 A receptor signaling in the paraventricular nucleus of the rat hypothalamus. Psychoneuroendocrinology. 2012:37:1248-60.

205. Deussing JM, Chen A, et al. Physiol. Rev. 2018:2225-86.

206. Bale TL, Vale WW. CRF and CRF receptors: role in stress responsivity and other behaviors. Annu Rev Pharmacol Toxicol. 2004;44:525-57.

207. Müller MB, Zimmermann S, Sillaber I, Hagemeyer TP, Deussing JM, Timpl P, et al. Limbic corticotropin-releasing hormone receptor 1 mediates anxietyrelated behavior and hormonal adaptation to stress. Nat Neurosci. 2003;6: 1100-7.

208. Deak T, Nguyen KT, Ehrlich AL, Watkins LR, Spencer RL, Maier SF, et al. The impact of the nonpeptide corticotropin-releasing hormone antagonist antalarmin on behavioral and endocrine responses to stress. Endocrinology. 1999;140:79-86.

209. Timpl P, Spanagel R, Sillaber I, Kresse A, Reul JMHM, Stalla GK, et al. Impaired stress response and reduced anxiety in mice lacking a functional corticotropin-releasing hormone receptor 1. Nat Genet. 1998;19:162-6.

210. Britton KT, Lee G, Vale W, Rivier J, Koob GF. Corticotropin releasing factor (CRF) receptor antagonist blocks activating and "anxiogenic" actions of CRF in the rat. Brain Res. 1986;369:303-6.

211. Bale TL, Contarino A, Smith GW, Chan R, Gold LH, Sawchenko PE, et al. Mice deficient for corticotropin-releasing hormone receptor-2 display anxiety-like behaviour and are hypersensitive to stress. Nat Genet. 2000;24:410-4.

212. Kishimoto T, Radulovic J, Radulovic M, Lin CR, Schrick C, Hooshmand F, et al. Deletion of crhr2 reveals an anxiolytic role for corticotropin-releasing hormone receptor-2. Nat Genet. 2000;24:415-9.

213. Catalano RD, Kyriakou T, Chen J, Easton A, Hillhouse EW. Regulation of corticotropin-releasing hormone type 2 receptors by multiple promoters and alternative splicing: identification of multiple splice variants. Mol Endocrinol. 2003;17:395-410.

214. Bao AM, Fischer DF, Wu YH, Hol EM, Balesar R, Unmehopa UA, et al. A direct androgenic involvement in the expression of human corticotropin-releasing hormone. Mol Psychiatry. 2006;11:567-76.

215. Chen X-N, Zhu H, Meng Q-Y, Zhou J-N. Estrogen receptor-alpha and -beta regulate the human corticotropin-releasing hormone gene through similar pathways. Brain Res. 2008;1223:1-10.

216. Rosinger ZJ, Jacobskind JS, Bulanchuk N, Malone M, Fico D, Justice NJ, et al. Characterization and gonadal hormone regulation of a sexually dimorphic corticotropin-releasing factor receptor 1 cell group. J Comp Neurol. 2019;527.

217. Van Pett K, Viau V, Bittencourt JC, Chan RKW, Li HY, Arias C, et al. Distribution of mRNAs encoding CRF receptors in brain and pituitary of rat and mouse. J Comp Neurol. 2000;428:191-212.

218. Bingaman EW, Magnuson DJ, Gray TS, Handa RJ. Androgen inhibits the increases in hypothalamic corticotropin-releasing hormone $(\mathrm{CRH})$ and $\mathrm{CRH}$ immunoreactivity following gonadectomy. Neuroendocrinology. 1994;59: 228-34.

219. Viau V, Soriano L, Dallman MF. Androgens alter corticotropin releasing hormone and arginine vasopressin mRNA within forebrain sites known to regulate activity in the hypothalamic-pituitary-adrenal axis. J Neuroendocrinol. 2001;13:442-52.

220. Uchida K, Otsuka H, Morishita M, Tsukahara S, Sato T, Sakimura K, et al. Female-biased sexual dimorphism of corticotropin-releasing factor neurons in the bed nucleus of the stria terminalis. Biol Sex Differ. 2019;10:6.

221. Funabashi T, Kawaguchi M, Furuta M, Fukushima A, Kimura F. Exposure to bisphenol A during gestation and lactation causes loss of sex difference in corticotropin-releasing hormone-immunoreactive neurons in the bed nucleus of the stria terminalis of rats. Psychoneuroendocrinology. 2004;29:475-85.

222. Seale JV, Wood SA, Atkinson HC, Lightman SL, Harbuz MS. Organizational role for testosterone and estrogen on adult hypothalamic-pituitary-adrenal axis activity in the male rat. Endocrinology. 2005;146:1973-82.

223. Fukushima A, Furuta M, Kimura F, Akema T, Funabashi T. Testosterone exposure during the critical period decreases corticotropin-releasing hormone-immunoreactive neurons in the bed nucleus of the stria terminalis of female rats. Neurosci Lett. 2013;534:64-8.

224. Weathington JM, Hamki A, Cooke BM. Sex- and region-specific pubertal maturation of the corticotropin-releasing factor receptor system in the rat. J Comp Neurol. 2014;522:1284-98.

225. Lim MM, Nair HP, Young LJ. Species and sex differences in brain distribution of corticotropin-releasing factor receptor subtypes 1 and 2 in monogamous and promiscuous vole species. J Comp Neurol. 2005;487:75-92. 
226. Weiser MJ, Goel N, Sandau US, Bale TL, Handa RJ. Androgen regulation of corticotropin-releasing hormone receptor 2 (CRHR2) mRNA expression and receptor binding in the rat brain. Exp Neurol. 2008;214:62-8.

227. Scott LV, Dinan TG. Vasopressin and the regulation of hypothalamicpituitary-adrenal axis function: implications for the pathophysiology of depression. Life Sci. 1998:62:1985-98.

228. Gillies GE, Linton EA, Lowry PJ. Corticotropin releasing activity of the new CRF is potentiated several times by vasopressin. Nature. 1982;299:355-7.

229. De Vries GJ, Duetz W, Buijs RM, van Heerikhuize J, Vreeburg JTM. Effects of androgens and estrogens on the vasopressin and oxytocin innervation of the adult rat brain. Brain Res. 1986;399:296-302.

230. de Vries GJ. Sex differences in vasopressin and oxytocin innervation of the brain. Prog Brain Res. 2008;170:17-27.

231. Bredewold R, Veenema AH. Sex differences in the regulation of social and anxiety-related behaviors: insights from vasopressin and oxytocin brain systems. Curr Opin Neurobiol. 2018;49:132-40.

232. Paul MJ, Terranova Jl, Probst CK, Murray EK, Ismail NI, de Vries GJ. Sexually dimorphic role for vasopressin in the development of social play. Front Behav Neurosci. 2014;8:58.

233. Nomura M, McKenna E, Korach KS, Pfaff DW, Ogawa S. Estrogen receptor- $\beta$ regulates transcript levels for oxytocin and arginine vasopressin in the hypothalamic paraventricular nucleus of male mice. Mol Brain Res. 2002;109:84-94.

234. Grassi D, Amorim MA, Garcia-Segura LM, Panzica G. Estrogen receptor alpha is involved in the estrogenic regulation of arginine vasopressin immunoreactivity in the supraoptic and paraventricular nuclei of ovariectomized rats. Neurosci Lett. 2010;474:135-9.

235. Zhou L, Blaustein JD, De Vries GJ. Distribution of androgen receptor immunoreactivity in vasopressin- and oxytocin-immunoreactive neurons in the male rat brain. Endocrinology. 1994;134:2622-7.

236. Hrabovszky E, Kalló I, Hajszán T, Shughrue PJ, Merchenthaler I, Liposits Z. Expression of estrogen receptor- $\beta$ messenger ribonucleic acid in oxytocin and vasopressin neurons of the rat supraoptic and paraventricular nuclei. Endocrinology. 1998;139:2600-4.

237. Simonian SX, Herbison AE. Differential expression of estrogen receptor alpha and beta immunoreactivity by oxytocin neurons of rat paraventricular nucleus. J Neuroendocrinol. 1997:9:803-6.

238. van Leeuwen FW, Caffe AR, de Vries GJ. Vasopressin cells in the bed nucleus of the stria terminalis of the rat: sex differences and the influence of androgens. Brain Res. 1985;325:391-4.

239. De Vries GJ, Wang Z, Bullock NA, Numan S. Sex differences in the effects of testosterone and its metabolites on vasopressin messenger RNA levels in the bed nucleus of the stria terminalis of rats. J Neurosci. 1994;14:1789-94.

240. Wang Z, De Vries GJ. Androgen and estrogen effects on vasopressin messenger RNA expression in the medial amygdaloid nucleus in male and female rats. J Neuroendocrinol. 1995;7:827-31.

241. Axelson JF, Leeuwen FW. Differential localization of estrogen receptors in various vasopressin synthesizing nuclei of the rat brain. J Neuroendocrinol. 1990;2:209-16

242. Tong WH, Abdulai-Saiku S, Vyas A. Testosterone reduces fear and causes drastic hypomethylation of arginine vasopressin promoter in medial extended amygdala of male mice. Front Behav Neurosci. 2019;13:33.

243. Pak TR, Chung WCJ, Hinds LR, Handa RJ. Estrogen receptor-beta mediates dihydrotestosterone-induced stimulation of the arginine vasopressin promoter in neuronal cells. Endocrinology. 2007;148:3371-82.

244. Albers HE. Species, sex and individual differences in the vasotocin/ vasopressin system: relationship to neurochemical signaling in the social behavior neural network. Front Neuroendocrinol. 2015;36:49-71.

245. Johnson AE, Barberis C, Albers HE. Castration reduces vasopressin receptor binding in the hamster hypothalamus. Brain Res. 1995;674:153-8.

246. Young L, Wang Z, Cooper TT, Albers HE. Vasopressin (V1a) receptor binding, mRNA expression and transcriptional regulation by androgen in the Syrian hamster brain. J Neuroendocrinol. 2000;12:1179-85.

247. Tribollet E, Audigier S, Dubois-Dauphin M, Dreifuss JJ. Gonadal steroids regulate oxytocin receptors but not vasopressin receptors in the brain of male and female rats. An autoradiographical study. Brain Res. 1990;511:129-40.

248. Gao X, Phillips P, Oldfield B, Trinder D, Risvanis J, Stephenson J, et al. Androgen manipulation and vasopressin binding in the rat brain and peripheral organs. Eur J Endocrinol. 1994;130:291-6.

249. Erigelmann M. Vasopressin released within the septal brain area during swim stress modulates the behavioural stress response in rats. Eur J Neurosci. 1999;11:997-1002.
250. Neumann ID, Krömer SA, Toschi N, Ebner K. Brain oxytocin inhibits the (re)activity of the hypothalamo-pituitary-adrenal axis in male rats: involvement of hypothalamic and limbic brain regions. Regul Pept. 2000;96:31-8.

251. Windle RJ, Shanks N, Lightman SL, Ingram CD. Central oxytocin administration reduces stress-induced corticosterone release and anxiety behavior in rats. Endocrinology. 1997;138:2829-34.

252. Windle RJ, Kershaw YM, Shanks N, Wood SA, Lightman SL, Ingram CD. Oxytocin attenuates stress-induced c-fos mRNA expression in specific forebrain regions associated with modulation of hypothalamo-pituitaryadrenal activity. J Neurosci. 2004;24:2974-82.

253. Windle RJ, Gamble LE, Kershaw YM, Wood SA, Lightman SL, Ingram CD. Gonadal steroid modulation of stress-induced hypothalamo-pituitaryadrenal activity and anxiety behavior: role of central oxytocin Endocrinology. 2006;47:2423-31.

254. Ochedalski T, Subburaju S, Wynn PC, Aguilera G. Interaction between oestrogen and oxytocin on hypothalamic-pituitary-adrenal axis activity. J Neuroendocrinol. 2007;19:189-97.

255. Neumann ID. Antisense oligodeoxynucleotide effects on the hypothalamicneurohypophysial system and the hypothalamic-pituitary-adrenal axis. Methods. 2000:22:227-37.

256. Mantella RC, Vollmer RR, Amico JA. Corticosterone release is heightened in food or water deprived oxytocin deficient male mice. Brain Res. 2005;1058: 56-61.

257. Dai D, Li Q-C, Zhu Q-B, Hu S-H, Balesar R, Swaab D, et al. Direct involvement of androgen receptor in oxytocin gene expression: possible relevance for mood disorders. Neuropsychopharmacology. 2017:42:2064-71.

258. Patisaul HB, Scordalakes EM, Young $\sqcup$, Rissman EF, et al. J Neuroendocrinol. 2003;15:787-93.

259. Sharma D, Handa RJ, Uht RM. The ER $\beta$ ligand $5 a$-androstane, $3 \beta, 17 \beta$-diol (3ß-diol) regulates hypothalamic oxytocin (Oxt) gene expression. Endocrinology. 2012;153:2353-61.

260. Hiroi R, Lacagnina AF, Hinds LR, Carbone DG, Uht RM, Handa RJ. The androgen metabolite, $5 a$-androstane-3 $\beta, 17 \beta-d i o l(3 \beta-d i o l)$, activates the oxytocin promoter through an estrogen receptor- $\beta$ pathway. Endocrinology. 2013;154:1802-12.

261. Johnson AE, Ball GF, Coirini H, Harbaugh CR, McEwen BS, Insel TR. Time course of the estradiol-dependent induction of oxytocin receptor binding in the ventromedial hypothalamic nucleus of the rat. Endocrinology. 1989; 125:1414-9.

262. Johnson AE. The regulation of oxytocin receptor binding in the ventromedial hypothalamic nucleus by gonadal steroids. Ann N Y Acad Sci. 1992:652:357-73.

263. Kudwa AE, McGivern RF, Handa RJ. Estrogen receptor $\beta$ and oxytocin interact to modulate anxiety-like behavior and neuroendocrine stress reactivity in adult male and female rats. Physiol Behav. 2014;129:287-96.

\section{Publisher's Note}

Springer Nature remains neutral with regard to jurisdictional claims in published maps and institutional affiliations.

Ready to submit your research? Choose BMC and benefit from:

- fast, convenient online submission

- thorough peer review by experienced researchers in your field

- rapid publication on acceptance

- support for research data, including large and complex data types

- gold Open Access which fosters wider collaboration and increased citations

- maximum visibility for your research: over $100 \mathrm{M}$ website views per year

At BMC, research is always in progress.

Learn more biomedcentral.com/submissions 